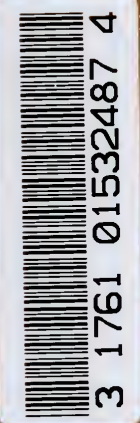
OK
477
G7
1915
c.1

EARTHSCI 
Digitized by the Internet Archive in 2007 with funding from Microsoft Corporation 




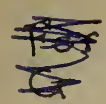

THE PERIODICITY AND DISTRIBUTION OF RADIAL GROWTH IN TREES AND THEIR RELATION TO THE DEVELOPMENT OF "ANNUAL" RINGS.

$\mathbf{B Y}$

J. G. GROSSENBACHER.

Reprinted from the Transactions of the Wisconsin ACademy of Scrences, Arts, and Letters, Vol. XVIII, Part I.

Issued October, 1915. 


$$
\begin{aligned}
& Q K \\
& 477 \\
& 67
\end{aligned}
$$




\section{THE PERIODICITY AND DISTRIBUTION OF RADIAL GROWTH IN TREES AND THEIR RELATION TO THE DEVELOPMENT OF “ANNUAL” RINGS.}

\section{J. G. Grossenbicher,}

\section{INTRODUCTION.}

The study of the so-called "annual" rings in trees has received the attention of numerous investigators during past years and still claims the interest of many. Research along that line, however, is not as active as formerly apparently owing to the general prevalence of the idea that the causes of ring formation are beyond our ability to fathom at present; although it is generally conceded that an environment resulting in discontinuous radial growth is somehow responsible for their occurrence.

In studying crown-rot of fruit trees ${ }^{1} I$ found that radial growth and especially its distribution on trees during late summer seemed to have a relation to the occurrence of the disease. A number of more or less incidental remarks had been noted in the literature concerning irregularities in the time of commencement and closing of cambial activity, but the irregularities occurring in fruit trees during late summer and fall were found so marked that the literature was more carefully examined. The number of significant papers on the subject proved so large and the conclusions drawn so varied and contradictory that it seemed desirable to discuss radial growth and the factors thought to determine its distribution in a separate paper before writing up

\footnotetext{
${ }^{1}$ Crown-rot, Arsenical poisoning and winter-injury. N. Y. State Agrl. Expt. Sta. Tech. Bul. 12:367-411. 1909.

Crown-rot of fruit trees: field studies. N. Y. State Agrl. Expt. Sta. Tech. Bul. 23: 1-59. 1912.
} 
the results obtained from a histological study of the early stages of erown-rot.

The purpose of this paper, then, is to summarize in some detail most of the important hypotheses and investigations dealing with the matter included in the title, to compare them with one another and to bring out their relation to the writer's observations. Thus collecting the widely scattered ideas and summarizing the records of research along this line, it is hoped will stimulate a wider interest in the causes of periodic growth in trees and encourage and lead to their reconsideration from a more modern or quantitative standpoint. In the main the aim is to restate the questions raised by the investigators, although sometimes in a modified form. A restudy of the structural and tension changes accompanying periodic growth may also lead to an investigation of the enzymes active during radial growth and to the effect which adverse changes of environment have upon them while in an active condition. In any case studies of this type will throw more light on the relation of a varying environment to vegetative and reproductive processes in woody plants and thereby increase the knowledge necessary for a comprehensive investigation of their diseases. Most of the diseases of trees which are of much economic importance and of most scientific interest begin in the bark, and their origin seems to have a definite relation to such radial growth and consequent bark tensions, the normal adjustment of which is interfered with by subsequent changes in the environment. Studies of that kind will also help to clarify and perhaps correct some misapprehension that may exist regarding the relation of mycology and physiology to plant pathology.

\section{Seasonal Periodicity of Growth.}

It is generally held that seasonal periodicity or the alternation of one or more growing and resting periods during the year is a more or less unalterable inheritance of perennial plants of temperate zones, but Klebs starting with his extensive investigations on the artificial control of periodicity in algae and fungi, ${ }^{2}$ has reached a very different conclusion regarding the periodic

\footnotetext{
${ }^{2}$ Klebs, G. Willkürliche Entwickelungsänderungen be Pflanzen. pp. 166. Jena, 1903.
} 
habit of such plants. ${ }^{3}$ He maintains that the periodic or discontinuous habit of vegetative activity in plants is due to an alternation of favorable and unfavorable seasons of the year or to a periodicity of the climate, and that it, therefore, may be made continuous by modifying the environment. From his experimental work he concludes that dormancy is due to a reduction in one or more of the factors essential for growth, such as temperature, moisture and mineral nutrients, below the required amount; and that when such conditions occur the further manufacture and accumulation of organic focds inhibits the action of the enzymes necessary for growth. A timely increase in the limiting factor is said to either prevent or terminate a period of dormancy in most cases. The reduction in the supply of mineral foods was found to be a very important factor in inducing dormancy and, therefore, raising the temperature and increasing the supply of water and mineral foods was often found to force plants into growth. Berthold ${ }^{4}$ also concluded that a reduction in the supply of nutrient salts is the chief factor inducing a cessation of terminal growth. This same conclusion was more recently drawn by Lakon ${ }^{5}$ who caused the buds of various deciduous trees and shrubs to open when cuttings were placed in Knop's solution. Klebs thinks that in many cases the individual periodicity of the different branches and twigs of a tropical plant are due to differences in transpiration and mineral nutrient supply of such structures. It is thought probable that there may be a periodicity in the supply of mineral nutrients in the tropies which at times becomes a limiting factor inducing partial dormancy. On the other hand Smith $^{6}$ maintained that elongation growth of various Ceylon plants is controlled chiefly by the temperature and water supply; sometimes one and then the other or perhaps both acting together as the limiting factors.

In his interesting study of the second growth occurring on

${ }^{8}$ Klebs, G. Über die Rhythmik in der Entwicklung der Pflanzen.

Sitzungsber. Heidelber. Akad. Wiss. Math. Naturw. Klass. 23. 1911. pp. 84 .

- Berthold, G. D. W. Untersuchungen zur Physiologie der pflanzlichen Organization. 2:131-257. 1904.

${ }^{5}$ Lakon, G. Die Beeinflussung der Winterruhe der Holzgewächse durch die Nährsalze. Ein neues Frühtreibenverfahren. Zeit. Bot. $4: 561-82.1912$.

- Smith, A. M. On the application of the theory of the limiting factors to measurements and observations of growth in Ceylon. Ann. Roy. Bot. Gard. Peradeniya. 3:303-75. 1906. 
trees Späth ${ }^{7}$ comes to still another conclusion. According to him the occurrence of the June elongation-growth which makes its appearance fairly regularly on vigorous young trees of oak and beech, is not determined by the environment but follows the close of the spring elongation period after a fairly definite interval of time, and may even develo'pduring a drought or while conditions are extremely unfavorable for growth. In Quercus the resting period between the spring and June growth was from 30 to 40 days and in Fagus from 15 to 20 days. It is said to last 9 to 16 days in the former and 13 to 24 days in the latter. The length of these second shoots is thought to depend chiefly upon the amount of available water and is usually but. not always less than that of spring shoots. The species with the June-elongation habit have a short but very active springgrowth period as compared with those not having the June growth. It was found impossible to prevent the June elongation growth by reducing the food and water supply and by lowering the temperature, nor could it be made to continue beyond the ordinary period by supplying heat, moisture and food conditions favorable for growth.

Späth also found that the second growth is made up of three types. In one kind the axillary buds of an elongating shoot develop into branches before they are fully formed. This happens in Salix, Populus, Taxus, Buxus, Prunus, Pyrus, and is called sylleptic growth. In the second type known as June growth (Johannestrieb) the buds are fully formed before they open after the termination of the spring elongation growth. The third type is called proleptic growth and is said to develop at any time during summer from buds which normally would not have opened until the following spring but which open early owing to wound or some other strong environmental stimulus.

Neither sylleptic nor June elongation-growth was said to have a zonation effect upon radial growth while the production of proleptic shoots practically always resulted in more or less distinct zonation of the radial growth. This was shown during their development by the wood cells produced being wider than those differentiated just before the new shoots appeared.

\footnotetext{
' Späth, H. L. Der Johannistrieb. Ein Beitrag zur Kenntniss der Periodizität und Jahresringbildung sommergrüner Holzgewächse. Berlin, 1912. pp. 91 .
} 


\section{The Beginning and Duration of Radial Growth.}

Observations and statements regarding the commencement of cambial activity or radial growth in spring are many but no positive conclusion can as yet be drawn as to just where on any particular species of tree it will begin one season after another. In fact it seems to differ considerably for individuals of the same species.

According to Strasburger ${ }^{8}$ in pines as well as in Picea, as many as five layers of tracheids had been formed from the eambium in one-year shoots and considerable elongation growth had occurred by the first of May, while at the bases and on the trunks of eight-year old branches the cambium was still inactive. In case of Robinia Pseudacacia and some other species, however, radial growth was found to begin first on the trunk. But in general cambial activity is said to begin in one-year shoots just back of the unfolding buds and to proceed downward to the larger branches and trunks on which it usually begins uniformly and at about the same time from top to bottom. He found that the cambium gives rise chiefly or almost exclusive to wood cells ${ }^{9}$ in spring, and as the regetative season advances, the production of phloem increases while that of wood cells decreases. In trees of our zone wood formation is said to cease by mid-August while that of the phloem continues practically up to the end of the vegetative season. Wood cells are therefore usually matured before winter but phloem cells sometimes enter the dormant season in an immature condition.

Pfeffer" also says that "the secondary growth of xylem in trees begins and ends sooner than that of the phloem."

Hartig11 states that although no growth had occurred on April 15 on any of the sixteen-year-old trees under observation, by May 5 the new radial growth in oak was about equal on all parts of the trunk but that none had occurred underground; while in maple, though the buds were farther advanced than in oak, the growth as yet was confined chiefly to the one-year shoots.

\footnotetext{
${ }^{8}$ Strasburger, E. Ueber den Bau und die Verrichtungen der Leitung. sbahnen in den Pflanzen. Histologische Beiträge 3:494. 1891.

1. c. p. $2 \$ 2$.

10 Pfeffer-Ewart. The Physiology of Plants. 2nd revised Ed. 2:207. 1903.

${ }^{11}$ Hartig, Th. Beiträge zur physiologischen Forst-Botanik. Aligem. Forst-u. Jagd-Zeit. 1857: 281-96. 1857.
} 
On pine and larch the greatest growth had occurred at the base of the trunks. By August 19 radial growth had ceased on above-ground parts of broad-leaved trees, only a small amount had occurred on the lateral roots and none on the fibrous roots. In conifers radial growth was not entirely completed on aërial parts and the roots were in about the same condition as those of broad-leared trees. In oak and maple radial growth on the fibrous roots began about the 1st of August, in pine about the 1st of September, in larch about mid-September. Hastings ${ }^{12}$ found that radial growth started first back of opening terminal buds in broad-leaved trees and proceeded basad. By the time the five to six-year branches were producing new wood radial growth had become general all over the trees. In case of pine radial growth commenced on the two to three-year old portions of branches and apparently before the buds opened. It was thonght that perhaps growth started on two-year branches in pine because leaves are retained two years, for it was noted that in the hemlock, where the leaves are retained six to seven years, radial growth seemed to have started first on six-year-old branches, while in the bald sypress radial growth started first just back of the opening terminal buds as in broad-leaved trees. On the other hand Knudson ${ }^{13}$ reports that radial growth begins on young trees of the American larch in the fourth to six-yearold branches. He holds that the cambium first gives rise to phloem cells in spring and that wood cells are developed later though his counts show only a few cells. The branches showing the first radial growth were found in the middie region of the tree. Here growth began at the apexes while in the trunk xylem formation is said to start near the middle. Darkened bark. owing to its heat absorbing qualities, is thought to induce early growth.

Aceording to Goff ${ }^{14}$ spring growth begins in many plants on their roots. From his examinations in late Narch he reports that the roots of Ribes vulgare had elongated as much as $7.5 \mathrm{~cm}$. (3 inches) before aërial growth had begun. Of the following

\footnotetext{
Hastines, G. T. When increase in thickness begins in our trees. Plant World. 3:113-16. 1900. Sc. 12:585-86. 1900.

${ }^{13}$ Knudson, L. Observations on the inception, season and duration of cambium development in the American larch. Bul. Torr. Bot. Club. 40:271-93. 1913.

14 Goff, E. S. The resumption of root growth in spring. Wisc. Agrl. Expt. Sta. Ann. Rpt. 15:220-28. 1898.
} 
species he says that root growth had also "started more or less in advance of the buds:" Picea excelsa, P. alba, P. pungens, Pseudotsuga Douglasii, Abies concolor, Thuja occidentalis, Pinus sylvestris, Tsuga canadensis, Tamarix amurensis, Acer saccharinum, Pyrus Malus, $P$. Communis, Prunus cerasus, $P$. virginiana, Betula alba, Morus alba, Cornus stolonifer, Eleagnus hortensis, Ribes nigrum and $R$. oxyacanthoides. When these observations are compared with those of von $\mathrm{Mohl}^{15}$ who found that, though radial growth in conifers has practically ceased by winter and that in deciduous trees it usually has not, it seems likely that Goff overlooked the possibility that portions he held to be new spring growth may have been very late growth of the preceding fall. Hartig $^{16}$ found that the roots of various forest and fruit trees had ceased radial growth in January, as judged by the thickness of the new ring and by the presence of starch in all of the ray cells of the cambial region. Russow ${ }^{17}$ made similar observations in regard to both forest and fruit trees. Hartig notes an exception in the case of a species of willow where radial growth of the roots had not been completed as shown by the thinness of the ring as well as by the absence of starch in the ray cells of the cambial region. Resa ${ }^{18}$ also made some observations which support Goff in some cases at least. He found that the roots of Picea and Fagus ceased growth in November and recommenced in February and March, while in case of Aesculus Hippocastan$u m$ and Tilia root growth ceased in October and recommenced in December or later. In Alnus glutinosa root growth began in October and continued practically through the winter except when the ground was frozen. Root growth began in late May in Acer campestre and in June in Quercus Robur. It is not usually considered that such enormous variations occur in the root growth of our trees and shrubs and for want of more detailed information it seems necessary to admit that at least in some

\footnotetext{
${ }^{15}$ von Mohl, H. Einige anatomische und physiologische Bemerkungen über das Holz der Baumwurzeln. Bot. Zeit. 20:225-30; 233-39; 268-78; 281-87; 289-95; 313-19; 321-27. 1862.

${ }^{16}$ Hartig, Th. Ueber die Zeit des Zuwachses der Bäume. Bot. Zeit. 21:288-89. 1863.

${ }^{17}$ Russow, E. Ưber den Inhalt der parenchymentischen Elemente der Rinde vor und während des Knospenaustriebes und Beginns der Cambiumthätigkeit in Stamm und Wurzel der einheimischen Lignosen. Stizungsber. Naturforscher-Ges. 6:386-88. 1884.

${ }^{18}$ Resa, F. Ueber die Periode der Wurzelbildung. Inaug. Dissert. Bonn. 1877. pp. 37 .
} 
cases root growth may precede the growth of aërial parts of trees in spring.

Schwarz ${ }^{19}$ found that radial growth may start in spring in various parts of trees depending on the environment. In case of a much shaded or overtopped tree it was found that radial growth had begun at the base, while half way up the trunk the cambium was still dormant. In another instance $43 \%$ of the ring had formed at the base of a tree by July 27, while $5.5 \mathrm{~m}$. up the trunk no growth had yet occurred. These irregularities are held not to be attributable to differences in temperature occurring at the different regions. Mechanical stimuli to be discussed later are held to be the instigators and distributors of radial growth.

THE RELATION OF FOOD DISTRIBUTION AND THE PRESENCE OF ELONGATING STRUCTURES TO THE OCCURRENCE OF RADIAL GROWTH.

It is of interest to know definitely what relation exists between the occurrence of radial growth and elongation growth or whether both are simply dependent upon the presence of certain unknown amounts of elaborated and inorganic foods in connection with the enzymes that may be involved in food transformations and growth. The experiments of Jost ${ }^{20}$ indicate that a casual relation exists between radial growth and some phases of elongation growth or the presence of unfolding buds, since on the removal of the buds from seedling beans radial growth practically ceased although elongation might continue. Starch was present in abundance and increased after the operation yet cambial activity remained in abeyance. All the elongation buds were removed from several years growth of branches of Pinus Laricio on March 8 while the dwarf branches and their leaves were allowed to stay. The dwarf branches which were nearly terminal then developed elongation buds. By the end of May but few tracheids had developed in the decapitated branches while in normal branches a new layer of about twelve tracheids was present, and they had become lignified. A month later the mutilated

\footnotetext{
10 Schwarz, F. Physiologische Untersuchungen über Dickenwachstum und Holzqualität von Pinus silvestris. Berlin. 1899. pp. 371.

* Jost, L. Ueber Dickenwachstum und Jahresringbildung. Bot. Zeit. 49:485-95; 501-10; 525-31; 541-47; 557-63; 573-79; 589-96; $605-11 ; 625-30.1891$.
} 
branches had a layer of tracheids not to exceed five or six while a branch from which all dwarf-branches or assimilating leaves had been removed on March 8 but on which the terminal buds had been left, had developed a layer of eighteen to twenty tracheids.

In another experiment Jost removed buds from branches in early May. When examined in fall it was found that at a certain point or line in the year's growth the radial diameter of the tracheids was suddenly reduced and then increased again, thus indicating the time when the buds were removed. The doubling effect on the wood ring resulting from the removal of the leaves at a certain time, has since been investigated by Kühne as noted below.

In a later paper Jost ${ }^{21}$ reports some further experiments along this line. Defoliated pine branches were found to undergo normal radial growth provided the terminal buds are not removed, though they may be kept in the dark; while when the last grown leaves and the terminal buds were removed very little or no radial growth occurred. Practically the same results were obtained following a similar experiment with Rhododendron. Holes were bored into the trunks of various trees in late September and covered to prevent evaporation. By mid-October callus formation had occurred in all but Tilia, even though general growth had ceased. That is, it appears that although cambial activity is usually started by leaf or shoot elongation wounding may also induce it, and that not the availability of food but a distal connection with some growing leaf-structures or buds is necessary for the occurrence of radial growth. This same phenomonon is also indicated by the results of an experiment wlth Periploca. Althongh this plant has bicollateral bundles, removing a girdle of bark prevented radial growth on the basad side of the girdle. Nördlinger ${ }^{22}$ had noted that in case of most trees from which the branches are removed in winter practically no radial growth occurred during the following vegetative season although in some instances slight growth resulted.

\footnotetext{
${ }^{21}$ Jost, L. Ueber Beziehungen zwischen der Blattentwicklung und der Gefassbildung in der Pflanze. Bot. Zeit. 51:89-138. 1893.

${ }^{22}$ Nördinger, $H$. Der Holzring als Grundlage des Baumkörpers. Stuttgart. 1871. pp. 47.

${ }^{23}$ Vöchting, H. Zur experimentellen Anatomie. Nachrichten Kgl. Ges. Wiss. Göttingen. 1902:278-83. 1902.
} 
Vïchting ${ }^{23}$ also found that decapitating herbaceous plants resulted in the cessation of radial growth of the stele though increase in diameter may result from the growth of the pith and cortical parenchyma. After such decapitated plants were budded cambial activity was resumed.

Reiche $e^{24}$ also notes regarding trees of Chili that radial growth begins after the buds burst and that it does not occur unless bud development precedes it.

The more detailed experiments by Lutz ${ }^{25}$ also give support to Jost's conclusions regarding the relation of growing leaves or huds to radial growth, and they show besides that other things being equal the distribution of food may also be a determining factor in the occurrence of radial growth. All the buds and leaves of six to ten-year old trees of Fagus silvatica and some of Pinus silvcstris five to seventeen years of age were removed at intervals from spring through the summer and the amounts of reserve starch and growth were determined. The buds were removed on March 20 from a Fagus which was about a meter high. Branches were examined for the distribution of starch and for radial growth on June 15, July 1, 15 and 30, August 10 and 20, on the 10 th of September, October and November, as well as December 5 and 23 . The adventitious buds were removed but continued to reappear, some large ones being removed on October 10. Only minor fluctuations in the starch content of the pith rays, wood and bark of the branches were noted through the summer with an almost entire disappearance of starch in December. The branches remained healthy-looking but no radial growth resulted. Similar trees were defoliated on May 20, June 15, July 1, 15 and 30, and August 28 respectively, and also freed of buds at intervals during the remainder of the growing season. Branches of these trees were also examined on the above dates. In the tree defoliated on May 20 no starch was found in the branches aside from traces which occurred in the pith and broad rays during midsummer, and even that had disappeared by August 20. Only a small amount of radial growth took place which had all occurred by July. On October 30 the stem or trunk was found to contain considerable starch at the ground or

24 Reiche, K. Zur Kentniss der Lebensthätigkeit einiger chilenischen Holzgewächse. Jahrb. Wiss. Bot. 30:81-115. 1897.

${ }^{23}$ Lutz, K. G. Beiträge zur Physiologie der Holzgewächse. Beiträge Wiss. Bot. 1:1-8. 1897 . 
crown in the pith, rays, and bark yet no radial growth had occurred at that point, while, $20 \mathrm{~cm}$. above ground where no starch was present, about $4 \%$ of the normal amount of radial growth had occurred. The thickness of the new growth in the trunk increased upward until at $75 \mathrm{~cm}$. above ground a maximum of $30 \%$ of the normal amount had occurred although no starch was present there. A little starch was present in the main root near the crown but none occurred in the laterals and no radial growth had occurred in them.

Corresponding results were also obtained with the other trees. The starch content and radial growth were found to have increased in each ease, until, in the tree defoliated on August 28, the amounts of both starch and growth were normal. It should be noted, however, in eases where defoliation induced much reduction of food and growth of the trunks, that a radial growth maximum usually occurred about 75 to $80 \mathrm{~cm}$. above ground, such as given above in detail. The year's growth of full-leaved, young trees was found to be in excess of that occurring in preceding years and their stareh content was very high throughout the summer.

Five young trees of Pinus silvestris were used in similar experiments; one being defoliated on each of the following dates: March 20, May 20, June 15, July 1, and August 30. The buds which had been left on the tree defoliated March 20 had burst by Mav 20, although the needles had not reached full size. On July 1 and 30 some more buds had burst and begun to develop needles. On June 15 small amounts of starch were present in the branches. On August 20 no starch was present and only from 4 to $20 \%$ of normal radial growth was found. On October 10 , when the tree was taken out traces of starch were still present in the base or crown of the trunk but none occurred in the roots. The roots had died and their bark had become loose and infested with nematedes. Brown spots occurred on the bark of the stem and the twigs were being eaten by insects. The new growth was very irregularly distributed over the stem. Around the circumference just above the ground growth varied from none to $8 \%$ of the normal thickness and from this point upward the variations were equally as marked.

In the tree defoliated on May 20 no starch was found during the summer, yet from 10 to $60 \%$ of the normal increase in thick 
ness had oeeurred. In the remaining three trees traces of starch were present which soon disappeared. The radial growth ranged from $25 \%$ to normal. The tree defoliated June 15 was dead by Oetober and the one defoliated in August by the following May.

The stems of the first four and of some untreated young pines were eut in 15 to $30 \mathrm{~cm}$. pieces in October and by December the bark on the treated-tree pieces was found to have loosened especially where considerable radial growth had occurred. The bark had split and was shrunken both in length and circumference; while that on the pieces from untreated trees adhered firmly to the wood. In December pieces were also cut from the branches of the last treated tree, the bark of which had lost its turgidity after the operation but regained it again. A discolored circle was found in the cambial region. Groups of undifferentiated wood cells had been ruptured or broken down and were discolored.

In his researches on the reserve food of trees du Sablon ${ }^{26}$ found that the carbohydrate content underwent farily definite seasonal changes which apparently occurred irrespective of the weather. On March 17 the roots of pear trees contained much more sugar and very much more starch than the stems and the total carbohydrate content of roots was also higher. In stems of chestnut trees the carbohydrate content reached a maximum in October and a minimum in May, while in roots the maximum came in September and the minimum in May. In case of quince the maximum in both root and stem was found in January with a minimum in stems in May and in roots in June. In peach the minimum in both root and stem came in May and the maximum in the stem in July and in roots in November. In willow both stem and roots were found to have a minimum of carbohydrates in April and a maximum in Oetober, but both the maximum and minimum were more extreme in the roots. In the case of raspherry bushes the roots had a minimum in April and a maximum in Oetober, while in the biennial stems a high earbohydrate content was maintained during the first summer with a maximum in October, followed by a slight depression and subsequently a lesser maximum in the seeond April. Afterwards a fairly constant

\footnotetext{
2e du Sablon, Leclerc. Recherches physiologiques sur les matières de reserves des arbres. Rev. Gen. Bot. 16:339-68; 386-401. 1904.
} 
decrease in the carbohydrates occurred until the end of the stem's life.

The observations by Fabricius ${ }^{27}$ on the distribution of food in large spruce trees throughout the entire year seems also to throw some light on the possible relation this may have to the inception of radial growth in spring. The first tree was cut in February. It was $25 \mathrm{~m}$. high, had 68 growth rings at the base and its lowest branches were $14 \mathrm{~m}$. above the ground. The bark of the stem $30 \mathrm{~cm}$. above ground had considerable starch in the medullary rays, and less in the parenchyma. The older phelloderm and ray cells contained less starch than the younger ones. Practically the same distribution of starch obtained in the entire bark of the trunk up to the first branches. From the branches upward the stareh gradually increased to a maximum at $21 \mathrm{~m}$. and diminished again near the distal tip where but little was present. The twenty-five outer rings in the lower part of the trunk had live, starch-bearing wood-rays and gum-canal cells and only the outer half of the youngest wood-ring contained no starch. Fifteen meters above ground where the stem had 36 rings only 19 contained live cells and at $18 \mathrm{~m}$. about a tenth of the ray cells were alive and starch bearing in the innermost of the 21 rings. In the one-year shoot only about half of the pith contained starch. The distribution of the fats was similar to that of the starch but it was much less in amount except in the youngest twigs. The decrease of reserve food near the distal portions was thought to be due to a loss through respiration during winter.

The starch content of small roots was slight but usually increased with their diameter up to 1 to $2 \mathrm{~mm}$. An excentric root having 55 rings on one side and 37 on the other contained starch in the outer 20 rings of the thicker side and in the outer 15 of the thinner. Only the roots over $2.5 \mathrm{~cm}$. in diameter contained fats. In some cases excentric roots were found to have a difference of as much as 50 growth rings between the broad and narrow sides, yet the cambium on the thinner side was normal, although it was evident that it often remained inactive during several years. The relative amounts of starch stored on the different sides of an excentric root was proportional to the amount of growth on any side.

${ }^{27}$ Fabricius, L. Untersuchungen über den Stärke-und Fettgehalt der Fichte auf der oberbayerischen Hochebene. Naturw. Zeit. Land-u. Forstw. 3:137-76. 1905. 
1 tree with 82 rings at its base and $22 \mathrm{~m}$. high was cut in March. The bark was fairly rich in starch from the ground up. The 3:2 outer rings of wood contained starch. At the first branches $12 \mathrm{~m}$. above ground, where the stem had thirty rings, only the fiftcen outer lings were alive and starch bearing. At a height of $18 \mathrm{~m}$. eleven or twelve of the fourteen rings present containel starch. Consiaberable starch occurred in the wood at the tree's base and decreased rapidly upward to a minimum about $3 \mathrm{~m}$. above ground, above which it gradually increased again to a maximum just below the branches. From this point upward a decrease occurred which reached a second minimum $18 \mathrm{~m}$. above ground, and was followed by a second increase upward to a maximum at the point where the stem inad but six wood rings. No fats could be found in the bark and very little in the wood. Apparently fats had been changeci to starch. MIore starch was present in the small branches of this tree than of the one cut in February. Both the wood and bark of the roots contained considerable starch except the youngest phioem cells which were devoid of it. In excentric roots the starch distribution was similar to that found in the former tree.

Another tree which was much like the one cut in March as to size, age, etc., was cut in late April. Its bark was rich in starch with the exception of the phloem about $8 \mathrm{~m}$. above ground where none occurred. The reduction in the number of live, starchbearing wood rings from below upward was about the same as in the other cases. The wood rays near the cambium were devoid of starch. A slight amount of fat was present in the bark, while that of the wood increased from a small amount at the base of the tree upward to a maximum in the smallest twigs where it exceeded the starch. In this case a starch maximum occurred also at the base of the trunk, while in the branch bearing part of the stem the starch was evidently being dissolved from the cambium inward and in increasing extent upward. Fats were abundant throughout the trunks and also present in the wood of the larger roots but absent from the bark of roots. But very little starch was present in the wood-rays at the base of the trunk and the season's growth of wood was devoid of starch, while the previous year's growth was almost free of it in mid-June. From this region upward starch-free peripheral wood increased up to the first branches, where it included the 
outer four rings. In the branch-bearing portion of the stem the outer rings again showed some starch. All the wood was rich in fats which usually exceeded the starch present. In the phloem only the youngest cells had appreciable amounts of fat. That is, in mid-July more fat and less starch is present in spruce than in June.

Very little starch occurred in the one-year roots but it increased in amount toward the thicker roots so that in four-year roots as much starch was present as there had been in the trees cut before. The bark also contained much starch but very little fat. No fat was present in the wood of the smallest roots but it occurred in the larger ones and increased upward. The new elongation growth of the roots and the bark on the thin ones, as well as the young wood and phloem, were devoid of starch although considerable was present in the large roots. Fat occurred in the root wood and in occasional places in the bark.

By the last of August an additional reduction had occurred in the fat content of the bark and the starch in the bark had also decreased from the ground upward while nearly the entire woot cylinder had become practically starch-free. The bark of the larger roots contained considerable starch but it was irregularly distributed. In the youngest phloem it was absent. The wood-rays in the larger roots and stumps had fairly large amounts of fat present. In general it may be said that the starch decreased in the aërial parts and increased underground since last examined in July. The transition occurring at the crown or stump where starch was less and fat more abundant than earlier in the summer.

On September 25 the bark of the stem contained considcrable starch but it was present in decreasing amount from the first branches upward to practically none in the season's growth of shoots. Nearly the entire wood cylinder was devoid of starch excepting a small amount at its base or crown and in the inner living rings. Both bark and wood were rich in fats especially in the rays. The maximum fat content occurred about $3 \mathrm{~m}$. above ground where starch was practically absent. All except the thin roots were comparatively rich in starch. In the wood starch increased toward the stump. The larger roots also contained considerable fat while the small ones had none.

On October 28 the bark of the stem near the ground contained 
very large quantities of starch, which gradually diminished upward to the branches where it increased again but none was present in the season's shoots. In the wood of the stump the starch was also abundant especially in the rays. It decreased upward to the branches and in the season's shoots only a little was prescut near the pith. The fat content of the bark increased from the ground upward but beyond the four-year-old branches there was but little fat present. In general less fat than starch was present in the wood of the stem but it gradually increased from the ground up to the branches.

A marked starch increase in the wood since September was evident while the fat content had not been correspondingly reduced, in fact it was considerable in the branch-bearing part of the trunk. The distribution and relative amounts of reserve food was very similar to that found on the preceding February. It is therefore thought evident that starch does not diminish early in the dormant season and that it is retained as starch throughout winter.

The bark of the roots had an increasing amount of starch toward the stump until a maximum was reached in roots 2 to 3 $\mathrm{cm}$. in diameter after which it diminished. The wood contained considerable starch in as many as thirty of the outer rings near the stump and then the number of starch bearing rings decreased peripherally as it did in the stem from the ground upward. In an excentric root with a radius of $44 \mathrm{~mm}$. on one side and of 7 $\mathrm{mm}$. on the other twenty rings contained starch on the thicker side and ten on the other. The thicker side had 70 rings and the opposite side 20 showing that during 50 growing seasons no radial growth had occurred on the thinner side. The roots contained considerable fat which diminished toward the stump.

In this case as well as in the tree cut in February the youngest'phloem and the included portions of the phloem rays besides the outer cortex contained very little starch while that portion of the bark between them contained much starch. Fabricius thinks that the characteristic browning of the inner phloem so commonly noted in late winter and spring, which has been attributed to the action of atmospheric electricity by Tebeuf, ${ }^{28}$ ' probably has a relation to this distribution of reserve food in the bark.

Naturw. Zeit. Land-u. Forstw. 3:493-507. 1905.
} 
From these observations on reserve food distribution in large trees it seems evident that most of the starch is converted to fat during spring and early summer, and reconverted to starch again beginning in late September, so that the smaller portion of reserve food passes the winter as fat. Fischer's ${ }^{29}$ observations do not agree with those of Fabricius but, since the former based practically all his conclusions on specimens from stems ten years old or less his conclusions are not surprising.

According to Fabricius there is a general increase of starch also in spring but it is of short duration. By April 22 it had largely disappeared from both sides of the cambial region and more especially toward the top of the tree, i. e., apparently in proportion to cambial activity. At the same time the process of converting the reserve starch in the older rings to fat (which continues all summer) is also going on. The redeposition of reserve food is begun in the bark in the form of starch. In the wood this process does not begin till about the last of September and not until October is the fat in the wood cunverted into starch. The fat in the bark is used up during summer and, from the peripheral shoots downward, followed by a redeposition of starch as the second growth is finished in late summer. Elongation growth of roots is said to occur chiefly in June and July and again to a slight extent in October. During those periods they contained considerable fat which afterwards disappeared.

This series of examinations has shown that the fat content of roots is practically proportional to the amount of elongation growth in progress and that when this growth ceases very little or no fat is present, i. e., a causal relation seems to exist between - fat content and elongation growth. It is thought that perhaps the growing tip secrets an enzyme which is carried up the root by the "transpiration current," and which converts starch to fats. After the cessation of growth the fats are again changed to starch.

A more recent contribution to this discussion is by Preston and Phillips, ${ }^{30}$ but it also is based chiefly on determinations made on young trees. The study covered the period from October to

\footnotetext{
20 Fischer, A. Beiträge zur Physiologie der Holzgewächse. Jahrb. Wiss. Bot. 22:73-160. 1891.

so Preston, J. F., and Phillips, F. J. Seasonal variation in the food reserve of trees. Forest Quarterly 9:232-43. 1911.
} 
Jume and included both hard and soft wood trees. It was found that all stareh disappeared in winter from Populus deltoides, Salix alba and Junipcrus virginiana, while Qucrcus rubra, Ulmus americana, Acer saccharum and Juglans nigra retained considcrable starch in the wood throngh the winter. Titia americana nnderwent a starch rednction but retained some in the phloem, medullary rays, and xylem, while Carya glabra lost its starch in small stems but retained about a fourth of it in larger stems.

None of these trees exeept Carya showed a reduction of starch in the roots during winter. Large amounts of sugar were found present only in spring as the buds were unfolding. The trees tested had a maximum fat content in late fall and a minimum in spring. These tests seem to show that broad-leaved hard wood trees cannot be ealled starch trees nor those with soft wood fat trees, as had beeni done by Fischer.

Niklewski concluded from his study that the starch conversion in soft wood trees like Tilia, Betula, etc. is practically complete on the approach of winter, while in hardwood trees like Prunus and Syringa it is only partial. It was found that fats are more abundant in winter and also that a rise in temperature increased the amount.

According to $\mathbb{W}^{\top}$ otezal ${ }^{32}$ starch transformation begins in spring in the distal parts of shoots and roots and proceeds towards the older portions of the tree, although it starts later in roots than in the shoots. But normally these two waves of starch transformation starting in the roots and shoots do not encounter one another, and in this way a starch residue remains in the older wood and in the region of the root-crown. The deposition of starch then occurs in the reverse manner throughout the tree, i. e. it hegins in the oldest parts and around the root-crown and proceeds wave-like toward the distal ends of the shoots and roots.

The work by Fabricius reviewed above shows that remarkable and apparently wave-like progressive changes occur in the state and distribution of reserve foods in trees and that maxima and minima of the different types occur in certain parts at rather definite periods of the seasonal history. The above cited experi-

\footnotetext{
"Niklewski, B. Untersuchungen über die Umwandlung einiger stickstoffreier Reservestoffe während der Winterperiode der Bäume. Beihefte Bot. Centralbl. 19 Abt. 1:68-117. 1906.

${ }^{32}$ Wotczal, E. Die Stärkeablagerung in den Holzgewächsen. Bot. Centralbl. 41:99-100. 1890.
} 
ments by Lutz show in addition that food distribution in stems is related to the source and amount of elaborated food descending from the leaves although such factors do not seem to prevent the eventual regional distribution so strongly brought out by the observations of Fabricius, except in eases where the suppiy is very limited and apparently all used up or deposited on its way down the tree. At any rate, in such instances too little reaches the lower part of the trunk and roots to permit the occurrence of radial growth in those regions. Some recent defoliation experiments by Kühns ${ }^{32}$ show that the radial growth occurring after defoliation usually does not extend to the base of the stem and, therefore, results in an incompletc double ring. In this case as in those citcd by Hartig, Rubner, ete., the conclusion seems warranted that radial growth was omitted on the lower part of the trunk and roots chicfly because the downward stream of elaborated food is used up before reaching that part of the trunk. When the growth of excentric roots and an irregular distribution of radial growth at any given circumference of a tree-trunk, as noted by Lutz, are considered in relation to the oceurrence of reserve food, the problem becomes more complex. Such cases make it uceessary either to assume that elaborated food is thus irregularly distributed in a tree or else that other factors are involved in the distribution of radial growth. Fabricius found that food is stored in a larger number of rings on the thicker side of an eccentric root, but that does not necessarily mean that the oldest starch-bearing rings on that side are any older than the oldest starch-bearing ones on the thinner side since rings are often entirely omitted on the narrower side. It is at least possible that radial growth begins in spring in that portion of a tree in which the greatest amount of food is stored and in view of the fairly well established fact that growth continues longest in fall in such regions of maximum food content this possibility is somewhat emphasized. Perhaps it might be of interest first to consider the causes of execntric giowth as far as they have been determined before taking up the factors which have been advanced by several author's as the cause not only of the distribution of reserve foods but of the general form of tree trunks.

\footnotetext{
${ }^{8}$ Kühns, R. Die Verdoppelung des Jahresringes durch künstliche Entlaubung. Biblio. Bot. 70:1-53. 1910.
} 
THE CALSES AND THE OCCURRENCE OF EXCENTRIC RADIAL GROWTH.

In a study of the distribution of excentric radial growth on trees it is well to note that excentricity may conceivably come about in one or more of four ways and that in a sense such an uneven growth of a stem at any height corresponds to the wavelike uneven distribution at different heights of a tree. The four ordinary ways excentric stems may be built up are (1) by the entire omission of radial growth in a part of the circumference, (2) by the unequal rate of growth on different sicies of stems, (3) by the entire omission of summer growth on one side and, (4) by the omission of spring growth on a part of the circumference and its occurrence at other places. In looking over papers on excentric stems, etc., it is sometimes difficult to determine to which of the four classes the case under consideration belongs but usually that is apparent.

Gravity and other factors of the environment as well as the anatomic or physiologic characteristics of a species seem to be the causes of excentric radial growth but as yet the matter is not fully understood. That a difierence may be found in trees of different groups in regard to excentric growth, when subjected to the same enviromment, is shown by some observations by Nördlinger. ${ }^{34}$ He cites an instance in which saplings of conifers, heech, and cak had been bent over by the heavy snows of 1563 and afterwards grew in slanting positions. Three years later sections taken at any point of the stems showed that pine, spruce, and larch had developed three excentrie rings with the larger radius helow while on the oaks and beeches the three last rings were thicker above. In one spruce only one very narrow ring had been laid down on the upper side while the other rings had lee $\mathrm{n}$ who? $\mathrm{ly}$ omitted on that side. In both oak and beech radial arowth hod to $\mathrm{n}$ extremely slight on the under side during the three years. This shows that different trees subjected to the same environment may respond differently. That is, the specific characteristies of a plant to a certain extent determine the man1.er of response to the environment.

Miiller's $\mathrm{s}^{35}$ observations seem to indicate that if excentric

sis. $r$.

28 Müller, N. J. C. Beiträge zur Entwicklungseschichte der Baumkrone. Bot. Untersuchungen 1:512-24. 1877. Heidelberg. 
growth is due to the environment the branches on the upper and lower parts of the same tree must be dominated by different factors. On measuring the cross sections of 100 large horizontal branches of beech trees he found that of those arising on the stems between eight and fifteen meters above ground $36 \%$ were epinastic, $60 \%$ hyponastic and $4 \%$ of equal radius above and below; of those arising between fifteen and twenty meters above ground $36 \%$ were epi-and $39 \%$ hyponastic and $24 \%$ had equal radii above and below; of those taken twenty to twenty-four meters above ground $64 \%$ were epi-and $28 \%$ hyponastic, with only $7 \%$ having equal radii above and below.

This opened up a phase of the problem, which is often left out of consideration. It shows that the branches of some trees are chiefly hyponastic on the lower part of trunks while they may be predominately epinastic in the upper regions. From his tabulated data the unmentioned and highly interesting fact may also be gleaned that, of the 100 branches measured, 47 had the greatest diameter in the horizontal plane and only 28 had the greatest diameter in the direction of gravity, while the other 25 were isodiametric. Although no special attention was directed to these facts by Müller he apparently was fully aware of them for he concluded that gravity is not a factor in the distribution of excentric radial growth, but that its distribution depends upon illumination and the relative proximity to the channels of most direct or greatest water and food conductance. Wiesner ${ }^{36}$ who has given this problem much attention, says that all inclined stems of conifers are hyponastic or what he calls hypotrophic, and that those of broad-leaved trees with little or no anisophylly become first epinastic or epitrophic and eventually oiten become greatly hyponastic, while species with marked anisophylly are first hypotrophic and subsequently become epitrophic, and finally hypotrophic again. He maintained that excentric or heterotrophic radial growth of a branch is due to its position both in relation to gravity and to the axis from which it arises. On the other hand Gabnay ${ }^{37}$ concludes that the difference in the specific gravity of the elaborated food or of the cell content and the degree of regenerative power possessed by the different classes of

\footnotetext{
so Wiesner, J. Ueber das ungleichseitige Dickenwachsthum des Holzkörpers in Folge der Lage. Ber. Deut. Bot. Ges. 10:605-10. 1892.

:7 Gabnay, F. Die Excentrizität der Bäume. Just's Bot. Jahresber. $20: 100$. 1894 .
} 
tre's are the factors determining whether excentric growth shall he rpi- or hypotrophic. The specific gravity of the elaborated fool of conifers was found appreciably greater than that of broal-leaved trees. The regenerative power of a tree is said to be inversely proportional to the specific gravity of its elaborated food and it is held that the greater the regenerative power of a tree the more epitrophic it is, while the lower its regenerative power the more hypotrophic.

From his observations on the influence of the environment on radial growth $\mathrm{Kny}^{38}$ concludes that the excentricity of horizontal branches is not only a reaction to gravity but that it is also influenced by the relative illumination, transverse bark tension, etc., as well as by some unknown factors. In some plants the greatest thickness of one wood ring is on the lower side of a branch while subsequent rings may be thicker above. The hranches of most of the broad-leaved woody plants were found to have the upper half of the wood cylinder of greater thickness than the lower, but quite a number of exceptions were also noted, e. g. Tilia, Cydonia, Fraxinus, Gleditschia, Corylus and Alnus. The bramches of conifers on the other hand are thickened in excess chiefly on the lower side. In general it was found that one type of excentricity is characteristic of certain natural groups of plants, but isolated exceptions were often noted indicating that gravity plays a minor part in the distribution of radial growth. The upper side of branches is subject to greater variations of light, temperature and moisture than the lower and it was thought that perhaps bark tension might be less on the upper side owing to the greater distension of the bark on that side by the variations of the temperature; yet since the results may be just opposite in neighboring trees of different groups having the same enviromment no conclusions were thought admissible. It was observed that, owing to the fact that all leaves and buds attached to the under side of a lateral branch develop and grow most strongly, the axis is usually thicker on the lower side during the first year, while in subsequent years the branches on the upper side of a horizontal branch grow more rapidly than those on the lower and thus result in changing lyyponastic to epinastic branches. A case is cited where the stems of Ficus stipulata

${ }^{38} \mathrm{Kny}$, L. Ueber das Dickenwachsthum des Holzkoerpers in seiner Abhaengigkeit von aeussern Einfluesen. pp. 136. Berlin 1882. 
clambering up vertical walls were found to have both the wood and phloem portions of the bundles thicker and of larger cells on the wall than on the free side of ascending branches which is assumed to have become inherited dorsiventrality.

Kny's study of the roots of both hyponastic and epinastic species showed that no regularity occurs in the excentricity of radial growth and it was thought that local pressure relations may determine the excentricity in roots. The lateral roots were cut from small seedlings of Tilia, Picea and Gleditschia and, after they had begun to develop new roots, they were placed in darkened Knop's solution and allowed to grow. No excentricity resulted except in some cases where the upper radius was greater at the origin of the root from the axis. An examination of horizontal roots which had been exposed for years, showed that their excentricity is the same as that of the branches of the same tree. In a more recent paper $\mathrm{e}^{39}$ came to practically the same conclusions and maintained that the same factors which induce excentric growth in aërial structures are in the main responsible for their occurrence in roots. The atmospheric environment was thought somehow to be the causal agent.

A new and rather striking application of the bark-pressure hypothesis of Sachs and de Vries was made by Detlefsen ${ }^{40}$ in explaining excentric radial growth. He pointed out the obvious fact that on the concave side of a curved stem radial growth must necessarily decrease while on the convex side it increases bark pressure chiefly because of the effect such growth has upon longitudinal tension of the bark. Owing to the presence of the hard-bast fibers in the bark the reduction of the pressure on the cambium becomes effective some distance on both sides of the curve. The bark was usually found to be considerably thicker on the side of a stem having the greater radius and it was frequently wrinkled or at least more rugged. He held, therefore, that the excessive thickening in the upper angles of large lateral roots and in the lower angle of branches is due to the reduced bark pressure at those places following radial growth, and that the ridges extending from such roots up the trunks are secondary

\footnotetext{
${ }^{3} \mathrm{Kny}$, L. Über das Dickenwachstum des Holzkörpers der Wurzeln in seiner Beziehung zur Lothlinie. Ber. Deut. Bot. Ges. 26:19-50. 1907.

"D Detlefsen, E. Versuche einer mechanischen Erklärung des excentrischen Dickenwachsthums verholzter Aschen und Wurzeln. Arbeit. Bot. Inst. Würzburg. 2:670-88. 1882.
} 
effects of the same thing. In case of branches, it was assumed that their weight increases the longitudinal bark tension above and reduces it underneath. Trees having one-sided tops were said to also be affected by the increase of bark tension on the side with fewer branches and a decrease on the top-heavy side, thus resulting in excentric growth of the stem with the greater radius on the side having more branches. A case was described in which a large horizontal branch had a sharp lateral bend on the concave side, which had resulted in a marked increase in radial growth with only a slight increase on the lower side. On such an assumption as this of Detlefsen it is conceivable that, after the excentricity in the upper angles of lateral roots has once become marked and a tree has attained some age, it may become more and more pronounced until a buttress-like structure results. However, he failed to mention epinastic branches.

Kny ${ }^{41}$ has also noted that bending roots of herbaceous plants and allowing them to grow in the bent position results in excessive growth of both xylem and cortex on the concave side.

According to Mer ${ }^{42}$ the two chief causes for excentric radial growth are those affecting the manufacture of organic food and those influencing cambial activity. The factors affecting the former are the slope of the land, proximity to other irees, fertility of the soil, exposure, ete., while those influencing cambial activity are thought to be mechanical strains due to wind, gravity, traumatism, etc. Sloping ground is said to induce an increased growth on the hill and a reduced growth on the valley side. Trunks were more commonly found excentric in thick than in thin forest stands and the excentricity was confined chiefly to the lower parts. When affected by the proximity of another tree the radius toward the influencing tree was shorter. Curvature was held to be the most frequent cause of excentric growth. Wounds were found to induce an excessive radial growth on the opposite side of the stem; and excentricity was found to be conducive to the occurrence of frost clefts.

${ }^{41}$ Kny, L. Ueber den Einfluss von Zug und Druck auf die Richtung der Scheidewände in sich theilenden Pflanzenzellen. Jahrb. Wiss. Bot.
37:55-98. 1902 .

" Mer, E. Recherches sur les causes d' excentricité de la moélle dans le sapins. Rev. Eaux et Forêts. Ser. $2: 461-71 ; 523-30 ; 562-72$. 1888. $3: 19-27 ; 67-71 ; 119-30 ; 151-63 ; 197-217$. 1889. 
Cieslar ${ }^{43}$ performed an experiment which suggests the above cited observations by Nördlinger in that he bent over the tops of four eight-year-old spruce trees and tied them in a horizontal position in early summer, one was bent toward each of the four cardinal points. All ascending branches were also fastened horizontally. The trees were cut during the second winter following the beginning of the experiment and the radial growth was found to have become greater on the upright sasal portion of the stems on the side of the bent-over tops. The excentricity increased from near the ground up to a maximum beyond the middle point of the turn where the stem was horizontal. Starting in the outer ring some distance above the inception of excentric growth and extending even into the outer part of the third ring, the wood on the side having the longer radins had a reddish color, which also became darker upward in proportion to the inerease in the radius. That is, the rings produced the year before the trees were bent were also affected by the bending. It is also shown that the spring-growth of the affected rings is not discolored in the lower part of the stained region.

Such "red-wood" as described above is very commonly present in the under half at the base of pine and spruce branches. The physical properties of "red wood" have been studied in some detail and its histological characteristics have also recefved some attention. Although it seems not to occur in stem structure devoid of excentric growth, excentricity is not always accompanied by "red wood." The fact brought out in the above cited paper by Cieslar that the summer wood may be affected while the spring wood of the same ring is normal is especially noteworthy because it shows that the factors producing "red-wood" are not efiective throughout the year.

Hartig ${ }^{44}$ made an investigation of the occurrence and distribution of "red-wood" in spruce and found that it is always present on trees which have excentric trunks and are located in isolated places or in thin and interrupted forest stands. Since "red-wood" occurs in portions of trees which appear to be subject to the greatest strains, Hartig thinks it arises in response to the mechanical requirements of stems. He found that inclined

\footnotetext{
${ }^{43}$ Cieslar, A. Das Rothholz der Fichte. Centbl. Gesam. Forstwesen. 22:149-65. 1896.

"Hartig, R. Das Rothholz der Fichte. Forst. Naturw. Zeit. 5:96-109; $157-69.1896$.
} 
tree-trunks had a greater radius on the side toward which they slant and also have "red-wood" present on the side with the longest radius. In one instance a tree on the west edge of a forest and therefore having most of its branches on the west side was found to have a longer radius as well as abundant "redwood" on the east side. In another case trees along the western edge of a forest had the typical excessive growth and "redwood" on the east side of the trunks up to the age of about 80 to 90 years, after which the new rings showed a lesser excentricity and a smaller amount of "red-wood." The change seemed to have resulted from the presence of a new planting on the west side which had attained some size by that time. Hartig concluded that the mechanical or swaying effects of wind not only causes excentric radial growth but also induces the formation of "red-wood" on the side of trunks subjected to longitudinal compression. An instance is also eited in which the leeward side of a tree-trunk is excessively thickened from the base up but which was devoid of "red-wood" near the ground although it was abundant farther up. A case is described where the distal part of a young spruce stem had been bent into a complete turn and had grown in that position during 27 years. Sections cut at various points of the curve showed the occurrence of the greatest radial growth and of "red-wood" on the sides where gravity and longitudinal compression resulting from the top-weight and wind action would require it. The excentricity of large spruce branches and the accompanying "red-wood" was found to extend only about four meters out from trunks.

According to Hartig "red-wood" has comparatively large intercellular spaces and the cells seem not to be very firmly attached since they frequently fell apart in sections. The tracheids are said to have especially thick walls the innermost thickening layers of which are arranged spirally.

In a more recent summary of his investigations of wood Har tig $^{45}$ claims to have proved the relative influence of gravity and longitudinal compression in inducing the formation of "redwood." Spruce trees planted in large tubs were suspended in an inverted position in a greenhouse and the distal part of the stems were bent upward and allowed to grow during one sea-

\footnotetext{
${ }^{4}$ Hartig, R. Holzuntersuchungen. Altes und Neues. Berlin. 1901. pp. 99 .
} 
son. The excessive growth at the curve and the accompanying "red-rood" was found to have developed on the under or convex side of the curve. This was assumed to indicate that gravity has more influence in the production of "red-wood" than longitudinal compression.

Rubner ${ }^{46}$ has given us some interesting observations on excentrix as well as of more irregularly distributed radial growth of trees. He called attention to the fluted or furrowed trunks and buttressed trunk-bases so characteristic of certain species. He attributed the ridges to excessive and the valleys to subnormal radial growth. In Carpinus the deep, wide grooves in the stem were found to occur at places where several compound medullary rays are grouped together, while lesser depressions or channels occurred along each individual compound ray, but these lesser grooves were practically compensated for by the greater phloem production so that the outer surface of the bark did not show them. In portions of trunks represented by the ridges the rays were small and it was assumed by Rubner that the distribution of the large and small rays influences the relative amounts of radial growth of the ridges and valleys in the wood cylinder. While Nördlinger ${ }^{47}$ assumed that the valleys are due to an excessive bark pressure along the large rays owing to the development of stone cells or abnormally long phloem-ray cells in the bark at such places. He notes the absence of marked valleys and grooves in oaks devoid of broad rays. and that on very large, old trees the outer rings often have the valleys betwecn the large rays while the ridges occur along the rays. The armpit-like depressions below some branches, according to Rubner, occur under branches whose leaves elaborate only enough food for their own use thereby leaving the region just below the hranch bases insufficiently supplied, owing to the deflection the branch-bases cause in the downward current of food in the trunk. These depressions are said to be chiefly confined to epinastic species. In the valleys Rubner found the wood to consist mainly of thick-walled fibers and the radial arrangement of the cells was perfect, apparently because the valley-wood is devoid of vessels. The large "false rays" present in the valleys of Carpinus

\footnotetext{
${ }^{40}$ Rubner, K. Das Hungern des Cambiums und das Aussetzen der Jahrringe. Naturw. Zeit. Forst-u. Landw. 8:212-62 1910.

${ }^{47}$ Nördlinger, H. Wirkung des Rindendruckes auf die Form der Holzringe. Centralbl. Gesam. Forstwesen. 6:407-13. 1880.
} 
were found to develop in the second and subsequent annual rings by the elimination of most of the wood cells between adjoining rays. Lames ${ }^{48}$ has noted a similar compounding of the simple rays of white oaks. Rubner found that the ray cells in the valley wood are shorter than those in the ridge-wood. The wood in valleys often showed no indication of rings because the cells were frequently all of the summer-wood type with a reduced radial diameter. In the deep valleys many rings were found to converge into a homogeneous layer of small cells many of which had brownish contents. In some cases as many as twenty-two year's growth had occurred on the ridges while no growth resulted in the valleys. In some such instances the cambium in the valleys had become thick-walled and apparently lost its power of growth and in others it had died and turned brown. In the smaller valleys of trunks phloem production was found excessive while on the ridges it was only slight. Rubner also deseribed instances in which no radial growth resulted on the lower portion of tree-trunks during a number of years. He found that long branches with sparse foliage have very irregularly distributed radial growth, often being wholly omitted in some portions and present in others, although at times with imperfectly differentiated cells. Similar irregularities were also noted by Ursprung $^{49}$ in branches of teak wood from the tropies; cross sections showed that in some growing seasons the eambium had bcen active in only a part of the circumference.

The work reviewed above shows that several types of excentric radial growth oceur both in horizontal and upright struetures and that some of them are apparently due to differences in bark pressure and to an excentric distribution of the transpiraiton current and metabolized food, while in others the cause of the excentricity is not shown. For instance these authors have not determined why radial growth should be distributed in seattered patches on branches or tree-trunks which have an inadequate supply of food or why fluted trunks and buttressed stumps should occur, although Detlefson made some interesting suggestions regarding the latter. Rubner has shown that radial growth is very slight in the valleys or grooves occurring in the

\footnotetext{
"8 Eames, A. J. On the origin of the broad ray in Quercus. Bot. Gaz. 49:161-66. 1910.

" Ursprung, A. Zur Periodizität des Dickenwachstums in den Tropen. Bot. Zeit. 62: Abt. 1:189-210. 1904.
} 
trunks of Carpinus, etc., and that the wood of these valleys contains the large aggregate rays while that in the ridges has simple ones. That the presence of the aggregate rays has induced the valleys by their early cessation of growth as Sorauer ${ }^{50}$ held does not necessarily follow, though it may be true, as it is more recently implied by Bailey ${ }^{51}$ and others. In a number of recent papers written by Jeffrey's students ${ }^{52}$ it is maintained that the different types of rays and their method of development are of great phylogenetic significance in showing the paths of evolutionary development. Yet in the above cited paper by Bailey it is also noted that changed nutrition may markedly modify the rays and their distribution.

Some of Kny's ${ }^{53}$ results obtained in his experiments seem to indicate that the pressure under which rays differentiate in the cambial zone has much to do in determining their size. He found on applying a pinch-cock to twigs of Salix and Aesculus Hippocastanum in spring that not only was radial growth almost entirely inhibited on the comprassed sides but that the ray cells were broader in tangential direction and that in some cases a doubling of the typically simple rays had occurred in both trees. In the above cited paper on the causes of excentric growth Mer also calls attention to the increase of radial growth on trunks opposite a wound. This observation of Mer's is of interest here chiefly because the occurrence of traumatic rays ${ }^{54}$ in wood pro-

${ }^{50}$ Sorauer, P. Handbuch der Pflanzenkrankheiten. Zweite Auflage. $1: 537.1886$.

${ }^{51}$ Bailey, I. W. The relation of the leaf-trace to the formation of compound rays in the lower Dicotyledons. Ann. Bot. 25:225-41. 1911.

52 Bailey, I. W. Reversionary character of traumatic oak woods. Bot. Gaz. 50:374-80. 1910.

Eames, A. J. On the origin of the herbaceous type in the Angiosperms. Ann. Bot. 25:215-24. 1911.

Thompson, W. P. On the origin of the multiseriate ray of the Dicotyledons. Ann. Bot. 25:1005-14. 1911.

Holden, R. Reduction and reversion in the North American Salicales. Ann. Bot. 26:165-73. 1912.

Bailey, T. W. The evolutionary history of the foliar ray in the wood of the Dicotyledons, and its phylogenetic significance. Ann. Bot. $26: 647-61.1912$.

${ }^{6}$ Kny, L. Ueber den Einfluss von Zug und Druck auf die Reichtung der Scheidewände in sichtheilenden Pflanzenzellen. Jahrb. Wiss. Bot. $37: 55-98.1902$.

${ }^{5}$ Jeffrey, E. C. Traumatic ray-tracheids in Cunninghamia sinensis. Ann. Bot. 22:593-502. 1908.

Bailey, I. W. Reversionary characters of traumatic oak woods. Bot. Gaz. 50:374-80. 1910. 
ducerl on the side of a stem opposite a wound is assumed to have phylogenetic signifieance.

According to Groom ${ }^{55}$ the evolution of the rays in Quercus is rot as simple as presented by Eames, Bailey, Thompson and other's for he found cases where the primary rays seemed to hranch like those of beech described by Jost ${ }^{56}$ as well as others where the aggregations oecurred in the manner described in the above eited papers. Groom is inclined to the view that ray development and architecture is based on physiological rather than on phylogenetic factors and that it is impossible at present to decide whether the narrow or the broad-rayed type is the more primitive.

It is also worth noting that, although Nördlinger ${ }^{57}$ found the valleys originating along the groups of broad rays and that oaks without the broad rays are devoid of valleys, in case of very large old trees the ridges were often found to occur along the broad rays, while valleys were present between them, i. e. just the reverse of the conditions obtaining in younger specimens.

Perhaps it might prove worth while to find out whether the occurrence of valleys and ridges in such trees is due to differences between the rate of growth in the wood and in the rays rather than being due to an early cessation of ray growth as Sorauer had assumed. In ease the formation and radial elongation of ray cells were very slow as compared to the radial increase in the wood cylinder in general, it is conceivable that the solid broad rays may have a dominating influence and retard radial growth on both sides of them because of the firm attachment between the rays and the surrounding tissues. If the claim made by Klebs ${ }^{57}$ that the presence of large quantities of elaborated food retards radial growth should prove correct and since these large rays are the storage reservoirs for elaborated foods it would also be understandable how they might be comparatively slow growing in youth and comparatively more rapid in old age, when radial growth has become slow.

The conspicuous ridges on the lower part of trunks correspond

\footnotetext{
${ }^{56}$ Groom, P. The evolution of the annual ring and medullary ray in Quercus. Ann. Bot. 25:983-1003. 1911.

Jost, L. Ueber einige Eigenthümlichkeiten des Cambiums der Bäume. Bot. Zeit. 59:1-24. 1901.

-7 Nördlinger, H. Wirkung des Rindendruckes auf die Form der Holzringe. Centbl. Gesam. Forstwesen. 6:407-13. 1880.

${ }^{6}$ l. $c$.
} 
with the occurrence of the upper lateral roots. In trees like the elms, ironwoods, and oaks the excessive thickening in the upper angle primary roots make with trunks are often exaggerated into buttress-like enlargements which are continued as ridge-like prolongations extending some distance up the trunks. According to Detlefsen ${ }^{58}$ the excessive radial growth in the upper angle of lateral roots and in the lower angle which large branches make with the trunks is chiefly due to a continued decrease of the bark pressure at these places which results from radial growth. This hypothetical explanation, however, requires an experimental basis. The fact that the bark at these places is often cleft or ruptured rather shows that radial bark pressure, at least, occurs there. The pressure exerted against the bark by the growing wood is not only sufficient to bring about tension at the root and branch ridges but tension of sufficient magnitude to rupture the bark in many instances. The experiments by Vöchting ${ }^{59}$ in which the distal tips were cut from Helianthus and other plants with the result that the stems became somewhat fleshy and in some cases rib-like thickenings developed over the leaf traces and ran some distance down the stem, can scarcely be said to apply owing to the fact that in Vöchting's experiments the excessive thickening was chiefly due to increase in the pith and cortical parenchyma instead of radial growth of the stele.

It has been suggested or inferred by some of the above as well as by other writers that greater cambial activity occurs in the upper angle of roots at their origin from the stump than takes place in the lower angle, because the downward current of metabolized food is checked and accumulates more or less in the upper angle. The lower angle of the root is said to be more indirectly and, therefore, more sparsely supplied with food and for that reason one sided radial growth results. An additional factor, which contributes to this excentricity, is doubtless the pressure of the tree's weight on the cambium of the underside and another may be the reduced longitudinal bark tension suggested by Detlefsen. Even in case of a tree with a deeply penetrating tap root a very marked radial increase on the lower side of large primary laterals would tend to elevate the entire tree, and a tree without a tap root must be carried chiefiy by the large 
mimaly laterals and therefore exerts great pressure on the ('umlium as 1)etlefsen ${ }^{60}$ maintained.

Aeerring to another group of investigators to be eited in the diseussion on the distribution of radial growth, excentric growth is not due to an independent distribution of metabolized food and the other fartors commonly assumed to be effective. Both food and growth are held to be distributed by the mechanical effects of the environment in conjunction with the weight effects of the structure in question or by the rate and path of the transpiration current.

PHE GFNERIL FORM OF TREE-TRUNKS AND THE DISTRIBUTION OF R.ADIAL GROWTH.

The listribution of radial growth on trees determines the form of the stem and therefore its value as timber. Owing to the economic importance of the shape of tree-trunks to the lumbering industry forester's studied the distribution of radial growth and its relation to the enviromment very extensively and have collected many valuable data. Since the stem of a tree grown in a. fairly dense and uniform forest stand is relatively longer and less tapering toward its upper end, free of branches and therefore of more lumbering value than one grown in the open, the differnees in the environment of the two types have received much attention.

Nördlinger ${ }^{61}$ noted that the rearly increase in thickness on the hranchless and branched parts of stems grown in a forest diffrred from each other. The annual distribution of radial growth on the hranch-bearing portion in a forest stand was found to be similar to that on the entire trumk of a free-standing tree, which bears branches nearly to its base. The thickness of the wood rings in the branch-bearing part of stems was found to decrease from the has uprard. On the hranchless portion of trunks in dense forest stands the thickness of the recent rings was noticed

- to have decreased from the branches downward although in some cases the thickness of the new yearly growth remained practically constant at the base of trunks. He thought that the presence of clahorated food was not the only requisite for the occurrence 
of radial growth in any particular region of a tree-trunk for the reason that the radial growth maxima in dense stands move upward more rapidly than would be demanded by the reduction in metabolized food.

Sanio $^{62}$ noted that in case of a dwarfed fourteen-year-old sapling of Fraxinus excelsior growing in a swamp the spring wood was for the most part very thin and usually had but a single row of vessels while in some parts of the stem the rings were devoid of vessels. He thought it likely that spring growth had been wholly omitted at such places and that the ring there contained only summer-growth wood.

R. Hartig ${ }^{63}$ has probably published more on the general distribution of radial growth than any other investigator. From a study of overtopped pines and spruces between 20 to 30 years old, he found that the rings became thinner from the branched top downward and that in some cases as many as seven rings had been entirely omitted on the lower part of stems. When rings had been omitted during a series of years the lower edges of the new rings or wood-sheaths were found to have receded farther from the base each year. In another paper he ${ }^{64}$ called attention to the fact that in overtopped trees a reduction occurs in the yearly amount of wood produced from the branches downward.

In general a stem is said to have three more or less distinct growth regions in each of which a typical distribution occurs. ${ }^{65}$ In the main axis of the branched top the cross sectional area of the growth rings is said to increase from above downward. The rings on the branchless shaft also increased in thickness from the branches downward in trees having a well developed top, but as stated above, the reverse was found true of a dominated tree with a small top.

A more detailed study of the distribution of radial growth was carried out by Hämmerle ${ }^{68}$ in connection with his observations

\footnotetext{
${ }^{\circ 6}$ Hämmerle, J. Zur Organization von Acer Pseudoplatanus. Biblio. Bot. 50:1-101. 1900 .

-2 Sanio, K. Verleichende Untersuchungen über die Zusammensetzung des Holzkörpers. Bot. Zeit. 21:391-99. 1863.

${ }^{6}$ Hartig, R. Das Aussetzen der Jahresringe bei unterdrückten Stämmen. Zeit. Forst.-u. Jagdwesen. 1:471-76. 1869.

*4 Hartig, R. Zur Lehre vom Dickenwachsthum der Waldbäume. Bot. Zeit. 28:505-13; 521-29. 1870.

${ }^{\circ}$ Hartig, R. Ueber den Entwicklungsgang der Fichte im Geschlossenen Bestande nach höhe, Form und Inhalt. Forst. Naturwiss. Zeit. $1: 169-85.1892$.
} 


\section{Wisconsin Academy of Sciences, Arts, and Letters.}

on the elongation growth of young maple trees. He found that the greatest thickness of each ring normally occurred in the hypocotyledonary or crown region of young trees. The second ring of the branches was thicker toward the end than in the middle but subsequent rings decreased regularly toward the distal end. The third ring of a rather dwarfed, overtopped specimen had its greatest thickness in the three-year-old branches and diminished toward the base until at the height to which the tree had grown by the end of its first year, the ring was almost invisible; at the hypocotyl or crown region and at least as far as 19 ('m. downward on the roots no growth at all had occurred during the third year. The bark in all cases was thickest at the hypocotyl or crown region.

From the papers cited in this section as well as from others noted elsewhere it is very evident that the distribution of radial growth is at least quite strongly influenced if not entirely determined by the environment and it will be interesting to examine some of the papers in which the factors that have been advanced as being the regulators of this distribution are discussed.

The publication of Schwendener' ${ }^{67}$ epoch-making paper on the mechanical principles underlying the structure of Monocotyledons gave a view of plant anatomy from a new angle and still exerts a marked influence on both physiology and anatomy. Many measurements and calculations obtained from typical Monocotyledons are presented in this paper in support of the hypothesis that plant structures take on forms and have the supporting tissues distributed in them in such a fashion as to meet the mechanical requirement necessary to make such structures most efficient in carrying their own weight as well as in resisting injurious bending by the wind, etc. In replying to some severe eriticism of this paper he ${ }^{68}$ admitted that many inaceuracies occur in the calculations but maintained that on the whole it is correct. The general principle developed in the first paper is here also reinforced in its application to Dicotyledons but in a less thoroughgoing way. It was noted that radial growth in a tree-trunk seems to be distributed in a manner so as to meet the

\footnotetext{
" Schwendener, S. Das mechanische Princip im anatomischen Bau der Monocotylen mit vergleichenden Ausblicken auf die übrigen Pflanzenklassen. pp. 179.1874.

" 8 Schwendener, S. Zur Lehre von der Festigkeit der Gewächse. Sitzungsber. K. Preuss. Akad. Wiss. Berlin. 1884:1045-70. 1884.
} 
mechanical needs in supporting the top in its environment. The general form of trunks was found to conform more or less completely with shafts constructed to be of equal endurance throughout and capable of supporting a given load (top) and wind-pressure. It is said that owing to this fact a tree trunk grown in the open and therefore bearing branches nearly to the ground is thicker at the base than one grown in a forest and crowded by other trees.

Some years later Metzger ${ }^{69}$ published some results and observations from which the striking conclusion is drawn that light, warmth, moisture and food enable a tree to grow but that the wind determines how it shall grow. He points out the self-evident but none the less interesting fact that a tree-trunk must not only carry its own weight and that of the branched top but also resist the wind action as it shifts the center of giavity while swaying to and fro. The tree stems are said to be the pillars of the forest and in order that the forest exist they must be both rigid and at the same time elastic enough to withstand strong winds. This is illustrated by him by imagining a wooden shaft firmly fixed in a horizontal position at one end and weighted at the other, thus resulting in the greatest strain at the place of attachment. If such a shaft is to be equally liable to break at any point of its entire length its cross sectional area must decrease from the point of support to the application of the weight or force in accordance with the physical laws involved, and the most economical use of the material of the shaft would require such a construction. By making numerous measurements and calculations it was found that the proportional thickness and form of tree-trunks below the branch-bearing tops was practically that required of the shaft described above, except that most of them are enlarged at the base or root-crown beyond the hypothetical requirements. It is noted that tap-rooted trees in deep soil are devoid of the excessive basal enlargement, and it is therefore thought that the enlargement is only a result of developing an adequate root anchorage for the tree. That portion of the stem in the branching top was also found to conform to such a shaft.

In case of horizontal branches it is held that their own weight overbalances wind action as a formative factor, while in upright

\footnotetext{
'Metzger, A. Der Wind als massgebender Faktor für das Wachsthum der Bäume. Mündener Forst. Hefts. 3:35-86. 1893.
} 
branches like in trunks wind effects predominate over the weight of the structures themselves as formative stimuli. Branches in positions intermediate between these two extremes are said to be correspondingly influenced by the two factors. Since conifers of various sizes were found to conform very closely to the hypothetical requirements, Metzger thought it logical to assume that wind and the weight of the supported structures themselves are the factors instrumental in shaping tree-trunks or distributing radial growth on them. When the lower branches of a freestanding tree were removed, it was found that the annual growths on the lower portion of the trunk were reduced in crosssectional area in very nearly the proportion required by the hypothetical considerations of the upward movement of the point of greatest stress. When a free-standing tree is encompassed by young trees radial growth of its trunk decreases from above downward as required by this hypothesis. When forest trees are left free-standing by the removal of surrounding trees radial growth is found to increase on their trunks from above downward and to decrease below normal on the upper part of the stems. In conformity also with the above hypothetical requirements the tall or over-topping trees in a forest of mixed sizes undergo most radial growth on the lower parts of the trunks while the overtopped trees grow more on the upper part of trunks.

Although these conclusions were based on data, which were obtained from spruce, Metzger ${ }^{70}$ thinks them applicable to the distribution of radial growth of trees in general. According to him the wind, acting as a stimulus through its mechanical effects upon trees, also regulates in a general way, the distribution of the elaborated food as well as that of radial and elongation growth in accordance with the relation of the form of the top, etc. to wind-exposure. It is said that during the first and second year after the thinning of a forest most of the available food is used up in increasing radial growth on the lower part of the trunks so as to increase the wind resisting power of the suddenly exposed trees, but afterwards elongation growth proceeds rapidly. In some cases of this kind it is held that the top may be

\footnotetext{
${ }^{70}$ Metzger, A. Studien über den Aufbau der Waldbäume und Bestände nach statischen Gesetzen. Mündener Forstl. Hefte. 5:61-74. 1894. Mündener Forstl. Hefte. 6:94-119. 1894.
} 
deprived of marked radial as well as elongation growth for several years, and the long-continued scarcity of food in the upper part of the top is said often to result in the dying back of the upper branches and thus gives rise to stag-horn effects. The length of time required for adjustment to the new environment is said to depend upon the extent of a tree's leaf surface. The sprouts, which often arise on long bare trunks, are thought to be induced by the swaying action of the wind thus tending to develop a lower head.

An enormous amount of data and calculations on the relation of the environment to radial growth and its distribution was also callected by Schwarz ${ }^{71}$ and published as a monograph which in addition contains many very important observations on the life and seasonal history of Pinus silvestris. It is noted that yearly radial growth as measured by the area of its cross section increases in trees until the age of about 20 to 30 years is reached, but under very favorable environmental conditions its growth may increase to the age of 100 years. His general conclusions regarding the wind in its relation to the distribution of radial growth are practically the same as those put forth by Schwendener and Metzger. Some instances are cited where the tops of trees had been broken off when about 30 years old and which had since grown about 60 years with lateral branches diverted to function as the main axis. In the region of curvature of the branch which assumed the functions of the main axis excentricity became very marked, with the greater radius on the under side. It is thought that the excessive pressure or welght on the under side was the stimulus to increased radial growth on that side. In one case, in which the curvature induced had been such as to exert the greater pressure on the upper side in one place, it was found that this upper side had the greater radius. Many measurements on vertical stems also showed a greater radius on the leeward side in regard to the prevailing wind. By tying a young pine tree in a bent position excessive growth resulted on the compressed side, i. e. it seems that a fixed, bent position exerts the same influences on radial growth as the discontinuous pressure due to wind swaying. Other measurements on slightly inclined trees also showed a greater radius on the side toward which the trees inclined. It is held that relative amounts of 
elaborated foods present in different regions of trunks is not primarily responsible for the distribution of radial growth, for on such an assumption the greatest growth would always occur on the stem just below the branches, while as a matter of fact it usually occurs within two meters of the ground. In fact it is claimed that both the distribution of metabolized food and radial growth are regulated by the wind-pressure-and-weight stimuli. The wind effects are thought to induce the transfer of most of the food elaborated in the leaves of a recently isolated tree to the lower part of the trunk where increased radial growth is caused by the increase of the mechanical wind-stimulation. Attention is called to the fact that in case of excentric annual rings the excentricity is chiefly due to an excessive production of the socalled summer wood, thus upholding the view that swaying and weight stimuli are especially effective during the latter part of the period of radial growth. The data seemed also to show that after trees with excentric rings are perhaps about 73 years old or have begun to decline in their rate of growth the new rings decrease markedly in excentricity and in conformity with that it is noted that late season growth is less in trees which have reached the age of decline in growth rate.

Schweinfurth ${ }^{72}$ reported that about the Red Sea tree trunks all have a greater radius on the south side owing to the occurrence there of a continued and strong north wind during the summer. The presence of reduced branches on the north side is thought to have caused the reduced growth on that side.

A more detailed application to Schwendener's mechanical principles of plant structure to excentric radial growth in branches was made by Ursprung. ${ }^{73}$ He maintained that the distribution of radial growth of both stem and branches is determined by the compression-strain stimulus resulting from the weight of the structure and the action of the wind. Non-vertical stems and branches were usually found to have an elliptical cross section with the longer diameter in the direction of gravity. This is said to increase the carrying capacity of the wood because the force required to bend such a branch in a vertical plane is proportional to the third power of the vertical diameter and to

\footnotetext{
${ }^{72}$ Schweinfurth. Sitzungsber. Ges. Naturfor. Freunde. Berlin 1867. p. 4 .

${ }^{73}$ Ursprung, A. Beitrag zur Erklärung des excentrischen Dickenwachstum. Ber. Deut. Bot. Ges. 19:313-26. 1901.
} 
only the first power of its horizontal diameter. He also concluded that vertical stems may become excentric owing to onesided action of wind but that the effect on some trees might be different on account of variations in the shape and the consequent distribution of the weight of the top. The crooks in a tree trunk are assumed also to be gradually eliminated by the distribution of the radial growth in response to strain stimuli. The same laws are thought to apply to the radial growth in roots but because of the variation in the environing soil they are not always so regularly effective.

Vöchting ${ }^{74}$ cut the tips from some potted one-year-old savoy plants and placed them with their pots in a horizontal position. $\mathrm{He}$ attached weights to some near their decapitated tips and allowed them to vegetate during some months. The vertical diameter of the stems was markedly increased in the regions of greatest strain while the stems of the check plants retained their cylindrical forms.

The far-reaching applicability of this wind-gravity hpyothesis originating with Schwendener and elaborated by Metzger and others, according to which tree-trunks and other stem structures have a form required of a shaft of equal endurance throughout, has recently been questioned by Jaccard..$^{75} \mathrm{He}$ holds that the hypothesis is untenable because measurements and calculations made by him on a number of spruce trees resulted in a nonconformity of the hypothetical and actual forms of their trunks. It was found that the portions of the trunks beginning with 5 $\mathrm{m}$. above ground and extending to about $9 \mathrm{~m}$. above ground were practically of the form and dimensions required of such a shaft but above and below that region the trunks were thicker than required by the laws of mechanies. In one instance described in detail, however, the trunk of a spruce practically conformed to the required hypothetical shaft.

Although much more frequent strong winds are said to occur in western Switzerland the trees there were not found to differ appreciably from those of eastern Switzerland where strong winds are few. Jaceard maintained that during the growing season the wind is too spasmodic to be a factor in the distribution 
of radial growth, and besides, he holds that the distribution of growth on a tree-trunk having concentric rings could not conceivably be dependent upon wind action. From the measurements and calculations it is concluded, however, that treetrunks are shafts of equal water conductance throughout. From insufficient data and non-convineing arguments it is concluded tion mentioned above, though larger than necessary for the windthat the diameter of tree trunks above and below the 5 to $9 \mathrm{~m}$. portion mentioned above, though larger than necessary for the windgravity hypothesis are of just the size required of a shaft of equal water conductance throughout. The morphogenic power of the water current is thought to be proportional to the rate of metabolism and transpiration. The rate of cambial division is held to depend upon and be controlled by turgidity, and the influence of the environment is thought to affect radial growth chiefly through the transpiration stream. In the calculation upon which this hypothesis is founded it was assumed that the water conduction is confined to the outermost ring or wood sheath.

This hypothesis has some defects in common with the one it is supposed to supplant in that the distribution of radial growth is assumed to be controlled chiefly by one factor, other factors being effective only in so far as the basic one is influenced. Jaccard has many difficult problems to solve before his hypothesis to account for the actual distribution of radial growth in trees can be considered a theory. The relation of the first radial growth and its distribution in trees to the transpiration stream in cases where such growth precedes actual unfolding of the leaves will need to be explained in the promised detailed study he is to publish in a future paper. Nor is it permissible to assume as a fact that the water current is confined to the outermost ring of wood, especially when it is recalled that in certain portions of trunks radial growth may be wholly omitted during a number of successive years, and that many cases of girdling are also on record in which trees operated on vegetated and fruited normally during several years.

Tieler $^{76}$ concluded that practically all water is conducted in

\footnotetext{
${ }^{76}$ Wieler, A. Ueber den Antheil des secundären Holzes der dicotyledonen Gewächse an der Saftleitung und über die Bedeutung der Anastomosen für die Wasser-versorgung der transpirirenden Flächen. Jabrb. Wiss. Bot. 19: 82-137. 1888.
} 
the last ring but in a more recent study $\mathrm{Jahn}^{77}$ made it appear that the entire alburnum may be more or less active in water conduction although perhaps as much as half or more of the water is thought to be carried up the last ring.

Some evidence of the fact that wind is both a formative and a limiting factor in plant growth is afforded by several scattered papers on the influence of wind on vegetation, a few of which might be briefly noted in this connection.

While making an experimental study of the effects of wind on vegetation Bernbeck ${ }^{78}$ obtained some interesting results. $\mathrm{He}$ found that both shoots and leaves of plants subjected to wind of $14 \mathrm{~m}$. or less per second were injured in proportion to the amount of swaying and bending induced and that even delicate leaves of shade plants are not injured by the wind if they are firmly held to prevent swaying or bending during the exposure. It was found that the production of organic food was reduced in leaves exposed to wind as compared to that accumulating in protected leaves.

Gilchrist ${ }^{79}$ reported that potted plants of Helianthus annuus subjected to artificial wind swaying and rocking did not grow as tall as the checks while the diameter of their stems exceeded that of the check plants. Some more recent observations by Cavara $^{80}$ show a similar effect of wind exposure on the structure of Iresine, Coleus, Aster, Zinnia, and Sempervivum.

Esbjerg $^{81}$ found that protecting various herbaceous plants from strong winds by means of sereens resulted in an increased yield. An increase of 16 to $31 \%$ above that of the checks was secured in the yield of grain from rye; the yield of ruta-baga roots was increased from 7 to $17 \%$ and of mangels from 3 to $18 \%$, while clovers and grasses showed a gain of from 4 to $23 \%$ as a result of wind protection.

\footnotetext{
${ }^{77}$ Jahn, E. Holz und Mark an den Grenzen der Jahrestriebe. Bot. Centbl. 59:257-67; 321-29; 356-62. 1894.

${ }^{78}$ Bernbeck, O. Der Wind als pflanzen-pathologischer Faktor. Inaugural Dissert. Bonn. 1907. pp. 116.

${ }^{79}$ Gilchrist, M. Effect of swaying by the wind on the formation of mechanical tissue. Report Mich. Acad. Sc. 10:45. 1908.

${ }^{80}$ Cavara, F. Some investigations on the action of wind on plant growth. Expt. Sta. Record. 25:224-25. 1912.

${ }_{81}$ Esbjerg, N. Experiments with windbreaks. Expt. Sta. Record $23: 435.1910$.
} 
Similar facts are also reported by Waldron ${ }^{82}$ from North Dakota. While from Porto Rico ${ }^{83}$ we learn that the northeast wind prevailing there causes eitrus trees to grow slowly and one-sided in unprotected places; the bark looks dead and the new shoots are variously twisted. A case is cited where two similarly planted eitrus groves are located across the road from each other but one is protected by a windbreak while the other is fully exposed. The trees had all been set three years and were bearing in the protected grove while in the exposed one they looked as though they "had just been set." Wind-exposed trees were also found heavily infested by scale-insects while the protected ones were practically free from the pest.

In a very recent paper $^{84}$ it is stated that the wind induces dwarfing and the rosette habit, although the structural modifieations are attributed to excessive transpiration.

A like conclusion was recently also drawn by Choux. ${ }^{85} \mathrm{He}$ found that the stems of Neptunia prostrata and of Ipomea reptans grown during the tropical dry season were not only smaller but that their vascular systems were much more strongly developed than in those produced during the wet season. Starch was abundant in the dry season plants and practically absent from those grown in the wet season.

The hypothesis advanced by Schwendener and subsequently elaborated by Metzger and Schwarz and the more recent one by Jaccard are so simple and imbued with such insidious directness that they are fascinating although not wholly convincing. After making a brief survey of the observations and experiments by Jost, Lutz, Fabricius, Rubner, etc., it seems as though the occurrence and distribution of radial growth could not be dependent on a single factor. It appears for instance that the distribution of elaborated food must in part at least depend upon its place of manufacture and on the channels of its transport, especially when the amount available is somewhat below the

${ }^{82}$ Waldron, C. B. Windbreaks and hedges. N. Dk. Agrl. Expt. Sta. Bul. 88. 1910. pp. 11.

${ }_{83}$ Tower, W. V. Insects injurious to citrus fruits and methods for combating them. Porto Rico Agrl. Expt. Sta. Bul. 10:16-20; 35. 1911.

${ }^{84}$ Kroll, G. H. Wind und Pflanzenwelt. Beihefte Bot. Centralbl. 30 Abt. 1:122-40. 1913.

${ }^{85}$ Choux, P. De l'influence de l'humidité et de la sécheresse sur la structure anatomique de deux plantes tropicales. Rev. Gen. Bot. 25: 153-72. 1913. 
actual needs. On the other hand from the work of both Jost and Lutz it is also evident that the presence of food, transpiration current and suitable environment alone do not result in radial growth when no developing buds or shoots are present; i. e., cambial activity seems somehow to be dependent upon elongation growth or some enzyme activated or produced by it. The determinations by Fabricius, however, have made it apparent that the distribution of reserve food in tree-trunks seems to be in accordance with some unknown law, which brings about maxima and minima of food storage in more or less definitely alternating regions. The marked differences in the amounts of reserve food in the regions of maxima and minima could not be attributed to differences in the storage capacity of the regions for such differences would have been noted, nor to the distribution of the branches because the wave-like succession of maxima and minima also occurred and it was usually most marked on the branchless portion of trunks. There is some indirect evidence to be had from the cited papers which tends to show that the places of the inception and longest duration of radial growth in a general way are the places of maximum food storage, and therefore gives support to Mer' ${ }^{86}$ contention to the effect that radial growth begins first where most food is stored and is most active and persists longest in such regions. The SchwendenerMetzger-Schwarz hypothesis suggests another way out of the difficulty by its assumption that wind action is responsible for the distribution of both metabolized food ant radial growth. But we cannot admit the far-reaching claim of these investigators that wind and gravity are the only formative factors concerned in the distribution of radial growth especially since light and transpiration have been shown to be powerful formative agents.

OBSERVATIONS ON THE DISTRIBUTION OF LATE RADIAL GROWTH ON FRUIT TREES.

While studying crown-rot of fruit trees during a series of years, I found that the initial bark injuries which afterwards result in the disease usually occurred in places at the base of

${ }^{86}$ Mer, E. Sur les causes de variation de la densite' des bois. Bul. Soc. Bot. France. 39: 95-105. 1892. 
tree trunks where radial growth continues late in fall. The observations made to determine the distribution of late radial growth showed that it is very irregularly distributed, yet that when it occur's it is confined to certain parts of trees. Cranefield ${ }^{* i}$ has called attention to the general variation of radial growth in branches. After two seasons observations he concluded "that a wide difference existed between trees of the same variety, age and extermal appearance, and that the difference was often greater between different branches of one tree than between different trees." In 1899 he found that the bark peeled readily on all branches of apple, pear, plum and cherry as late as August 15, and after that date the bark still peeled easily for some time on the larger branches. In 1900 the bark of branches over $1 \mathrm{~cm}$. in diameter slipped easily enough to make whistles as late as September 15, while two weeks later it would not peel from any of the branches.

Although observations like these of Cranefield show that marked variations may occur in the distribution of the last radial growth, it is apparent that its actual variation can only be determined by much more detailed examinations at numerous points not only of any one tree but of any one branch. Some of the above cited observations on the general distribution of radial growth and more especially those on excentric growth also suggest the inference that late growth is often very irregularly distributed and that it is perhaps frequently confined to regions of trunks and branches where excentric growth occurs. In a general way that represents the distribution of the late growth occurring in fruit trees.

Radial growth in apple and other fruit trees was most commonly found to continue latest in fall around the base of the trunk and its upper roots as well as about the bases of branches and around crotches; but in some cases other regions also underwent late growth. The distribution of late growth about the base of the trunk is apparently subject to many variations depending upon the place of origin of the large upper roots as well as on the size of the top. Usually the last growth occurs on the ridges of the roots approximately in the center of the rounded angle a root makes with the trunk, although in some

${ }^{87}$ Cranefield, F. Duration of the growth period in fruit trees. Wisc. Agrl. Expt. Sta. Ann. Rpt. 17:300-8. 1900. 
cases it was found to occur equally late in the upward extension of such a root-ridge on the trunk. Again, in some instances in which trees had only two large lateral roots making a rather narrow angle with each other, very late growth was found to occur in the valley-like angle between them. From an earlier paper $^{88}$ on erown-rot and the paper's eited there it is interesting to notice that the distribution of that disease on fruit trees conforms fairly closely to the distribution of late radial-growth occurring at the root-crown region. It was found that in cases where only a part of the bark was affected it was confined to the upper angles of lateral roots, or to the very deep angles between two large laterals.

Pruning fruit trees very heavily often results in a decided reduction in the thickness of the next annual ring toward the base of the trunk. This was found by pruning some fruit trees in one of the seedling apple orchards of the New York State Agricultural Experiment Station in early spring of 1912. The radial growth on the lower part of such heavily pruned trees also continued several weeks later than it did on nearby checks.*

The result seems to agree with those obtained by Jost, Lutz, and Kühns ${ }^{89}$ in that a reduction of the foliage beyond a certain amount resulted in greatly reducing growth toward the base of the stem.

As stated above observations made regarding the occurrence of crown-rot on fruit trees seemed also to show a possible relation of that disease to the distribution of late growth. Some New York apple orchards may be used to illustrate this relation. In one instance ${ }^{90}$ two varieties almost equally susceptible to crownrot were grown side by side and received the same treatment except that the Baldwin variety was pruned up high while the other or Ben Davis variety was allowed to grow largely unpruned and therefore low headed. The Ben Davis trees had been set for fillers and were not deemed worth the eare bestowed on the

\footnotetext{
${ }^{88}$ Crown-rot, arsenical poisoning and winter-injury. N. Y. State Agrl. Expt. Sta. Tech. Bul. 12:389-94. 1909.

* The writer wishes to thank G. H .Howe of that station for having the pruning done, and R. Wellington, now of the Minnesota Experiment Station, for making some of the collections of specimens from these trees into killing fluids.

${ }^{89} 1$. c.

${ }^{\circ 0}$ Crown-rot of fruit trees: field studies. N. Y. State Agrl. Expt. Sta. Tech. Bul. 23:18-20, 46, and plate 7. 1912.
} 
other varicty since they were to be removed after the Baldwins had attained some size. Nearly all of the Baldwin trees had the bark injured about a decimeter above ground during the winter of $1910^{-11}$, and over $80 \%$ had practically entire girdles of looscned or injured bark so that they had become worthless, while none of the low headed Ben Davis trees were affected. In another case $^{91}$ bark injury resulted high up the trunks of bearing trees after a severe pruning.

It was also found that radial growth is often very late in thick callus rolls about old eankers and sometimes on the under side, or on the concave side of crooks in horizontal branches. The bases of water sprouts or adventitious ascending shoots that arise on the larger branches of excessively pruned young apple trees also undergo very late radial growth and apparently for that reason are winter-injured in those regions; as in some cases discussed on pages 40 to 42 of the above cited paper on crown-rot. Very similar observations regarding the distribution of winterinjury in the bark of trees had been made by Nördlinger. ${ }^{92} \mathrm{He}$ also assumed that such places are injured because of their late growth.

The reasons for the occurrence of late radial growth at certain places on trees are doubtless the same as those underlying the general distribution of excentric growth, and have not been fully determined as yet. It seems, however, that the re-distribution of bark pressure incident to radial growth, the distribution of elaborated food, the location of the channels for water conduction, and the gravity-wind pressure effects advocated as factors which regulate the distribution of radial growth, may afford at least a partial explanation of the localization of late growth after they have been submitted to a more careful quantitative study.

WHAT CAUSES RADIAL GROWTH TO APPEAR AS " ANNUAL" RINGS.

The general distribution of radial growth in trees has also an indirect relation to the development of "annual" rings in that the proportion of spring and summer wood of a ring at any level of a stem is doubtless dependent upon the comparative distribu-

${ }^{21}$ 1. c. p. 24-27.

" Nördlinger, H. Die September-Fröste 1877 und der Astwurzelschaden (Astwurzelkrebs) an Bäumen. Centbl. Gesam. Forstw. 4:48990. 1878. 
tion and duration of growth, in the early and late season, over the different parts of a tree. That is, if in any particular region of a trunk radial growth starts very early in spring and continues rapidly to the end of the spring-growth period a considerable layer of spring wood will oceur in that region; while if spring growth starts late, proceeds slowly and stops rather early the thickness of spring wood would be slight. If the distribution of summer growth is such as to add but little to a region where spring growth had been heavy and much where spring growth had been slight, the rings resulting in the two regions would have a very different appearance. To continue the illustration further, if for some reason radial growth failed to occur in certain parts of a tree-trunk until after the production of summer wood had begun such parts would show only small-lumened, thick-walled cells in the ring; while had the summer growth been eliminated in regions where spring growth occurred the resulting ring would consist of spring wood only. From the papers cited above on the distribution of radial growth it is evident that all the cases illustrated here do actually occur even in the extreme forms used in the last illustration. It is apparent, therefore, that in some environments and especially on certain parts of trees the distribution of radial growth may have a marked influence not only on the type of the resulting ring but even on the nature of the wood in such portions of stems. This evident relation between the seasonal distribution of radial growth on a tree to the type of wood ring to be produced has reseived practically no attention, although in von $M$ ohl' $\mathrm{s}^{93}$ paper on the anatomy of roots it is noted that rings with only the spring type of wood seem to result owing to the entire omission of the summer growth; while Sanio ${ }^{94}$ suggested a similar idea regarding the absence of spring growth in parts of some rings of a dwarfed Fraxinus grown in a swamp. Lutz ${ }^{95}$ also noted the absence of summer wood in a pine, from which the buds had been removed in March, the little growth that occurred was spring wood. When the wood of roots or stems grown in certain environments consist largely of so-called spring wood, elaborate explanations are usually manufactured to show that the high 
water requirements of such habitats induce the formation of large vessels throughout the wood for the conduction of the water needed. This may be typically illustrated by a paper of von Lazniewski ${ }^{55 *}$ on alpine plans in which attention is called to the fact that the rings in mountain willows are much thinner and have a greater proportion of vessels per ring than those in trees of the same spccies grown in the valleys. Yet it was noted that the outer parts of the wood rings were usually only partially lignified, indicating that radial growth had been prematurely checked. The excessive number of vessels per ring of the alpine trees was interpreted as being due to the greater demands for water on the mountains, while the probable fact that the summer-wood portion of the rings had perhaps been wholly eliminated by the environment was not even mentioned. Practically the same observations although on a larger scale were made by Rosenthal ${ }^{96}$ in a later paper and the conclusion was drawn that the larger number of vessels per unit area of cross section in willows grown on the mountains is an adaptation to a higher transpiration rate.

A number of hypotheses have been elaborated in an endeavor to explain "annual" rings, and more or less data has been collected by their supporters to substantiate them but with indifferent success as judged by Krabbe ${ }^{97}$, who some years after publishing his last researches on the subject, maintained that ring formation cannot be satisfactorily explained with our present knowledge of the factors determining the size differentiating cells attain in different parts of the growing season, and of the ones regulating the thickness of cell walls in different parts of the rings.

It was recently pointed out by Klebs ${ }^{98}$ that periodicity in plant growth occurs in all regions of the world having a periodic climate, and that the dormant periods coincide with the cold periods of temperate climates and with the dry periods of the tropies. He noted too, that some trees have partial and irregu-

\footnotetext{
${ }^{25 *}$ Lazniewski, von, W. Beiträge zur Biologie der Alpenpflanzen. Flora, 82:224-67. 1896.

${ }_{90}^{9}$ Rosenthal, M. Ueber die Aushildung der Jahresringe an der Grenze des Baumwuchses in den Alpen. Inaug. Dissertation. Berlin. pp. 24.
1904 .

${ }^{97}$ Krabbe, G. Einige Anmerkungen zu den neusten Erklärungsversuchen der Jahringbildung. Ber. Deut. Bot. Ges. 5:222-32. 1887.
} 
lar periodicity even in regions of the tropies having what appears to be a practically non-periodic elimate.

In central Uruguay ${ }^{99}$ where the temperature never goes much below freezing and where late summer is a dry season, some trees have distinct yearly wood-rings, while in others more than one ring is produced in a year. Robinia Pseudacacia and Melia azedarach have fairly evident annual zones, but they also have imperfect secondary zones due to a concentric arrangement of large vessels. In Acacia the yearly zonation is less distinct but the last wood is usually made up of cells with a reduced radial diameter.

The measurements by Hall ${ }^{100}$ show that the trunks of trees in Uruguay usually increase in circumference during nearly ten months of the year, and that in some eases they even increased during the months of May and June (winter). He found, however, that the circumference of most trees decreased more or less during winter, the deciduous trees more noticeably than the evergreens. Ursprung ${ }^{101}$ found that a number of the evergreen trees and shrubs of a tropical locality without any appreciable periodicity of climate showed a zonation in cross sections of the stems without the presence of any evident histological difference in the wood of the different parts of zones. Some of these species are said to become deciduous in localities having a periodicity in the water supply with the result that the zonation of their wood becomes more marked. Holtermann ${ }^{102}$ also studied the relation of climate to radial growth in the tropies and came to the conclusion that the formation of growth rings in the wood is intimately connected with the occurrence of periods of markedly different transpiration rates, and that the larger vessels are developed to meet the demands of inereased transpiration. He holds that tropical trees growing in a saturated atmosphere most of the time have no indication of zonation in the wood even though they

${ }^{\circ}$ Christison, D. On the difficulty of ascertaining the age of certain species of trees in Uruguay, from the number of rings. Trans. Bot. Soc. Edinburgh. 18:447-55. 1891.

${ }^{100}$ Hall, C. E. Notes on the measurements, made monthly at San Jorge, Uruguay, from January 12, 1885, to January 12, 1890. Trans. Bot. Soc. Edinburgh. 18:456-68. 1891.

${ }^{101} 1$. c.

${ }^{102}$ Holtermann, C. Der Einfluss des Klimas auf den Bau der Pflanzengewäche. Anatomisch Physiologische Untersuchungen in den Tropen. pp. 249. 1907. Leipzig. 


\section{Wisconsin Academy of Sciences, Arts, and Letters.}

are deciduous like some species of Leguminosae, Guttifereae and Ficus. On the other hand it is noted that a seven-year-old tree of Theobroma Cacao had developed 22 radial-growth rings, and since it cast its leaves three times a year it is evident that the number of rings corresponded with the vegetative seasons of the tree. The real cause of zonation is thought to be an inherent characteristic of a plant though the environment induces its manifestation.

According to Dingler ${ }^{103}$ leaf-fall is more dependent on the age of the leaves than on the environment, for by cutting back deciduous trees in Ceylon some time before the normal period of leaffall the new crop of leaves which immediately came out was retained throughout the dormant season which is dry and very hot. Unfortunately the effect upon radial growth was not noted but from evidence given above it seems very likely that the periodicity of radial growth always follows foliar periodicity in deciduous trees whether natural or induced.

In another paper he ${ }^{104}$ reported that the folier periodicity of European fruit and forest trees grown in the highlands of Ceylon is very irregular even in different branches of individual trees. In late October the trees of Quercus pedunculata could be divided into five classes in regard to the condition of their foliage, ranging all the way from cases in which chiefly old spotted leaves were present (though some scattered buds were swelling) to instances where no old leaves were present and the new shoots occurred in all stages of elongation, although most of them were full grown. Qucrcus Cerris had a more uniform periodicity. In late October all trees bore two generations of leaves: the old ones hard and spotted, althought still green, and the young ones not yet full grown. In late November the old leaves had practically all fallen and the new elongation growth had been completed. European pears, peaches, cherries, plums and apples were found to have practically the same periodicity, producing two crops of leaves and flowers, though but one crop of fruit per year. The trees are often almost leafless some time

\footnotetext{
${ }^{105}$ Dingler, H. Versuche über die Periodizität einiger Holzgewächse in den Tropen. Sitzungsber. Math.-Physical. Kl. Kgl. Bayer. Akad. Wiss. München. 1911:127-43. 1911.

${ }^{104}$ Dingler, $H$. ưber Periodizität sommergrüner Bäume Mitteleuropas im Gebirgesklima Ceylons. Sitzungsber. Math.-Physical. Kl. Kgl. Bayer. Akad. Wiss. München. 1911:217-47. 1911.
} 
in February or March. All stages of bud and leaf are said usually to oceur in these trees.

An experiment similar to that performed by Dingler had previously been made by Wright ${ }^{105}$ in Ceylon. He lopped trees of Mangifera indica and Terminalia Catappa in May and new leaves developed from July to September, with the result that no new leaves were produced on these trees in February and March when others of those species developed new crops of leaves. Some of the plants develop new leaves once or twice and others several times annually, and immature leaves may be found during every month of the year. Only a comparatively small percentage of the Ceylon trees are said to be deciduous. Some rapidly growing species were found to become defoliated at the end of the first year and others at the end of the second; while the more slowly growing ones may vegetate as evergreens until the close of the fifth or sixth year before losing their leaves. Usually, after a tree has once lost its leaves it loses them annually but some species are deciduous only in youth and become evergreen later. Some of the so-called evergreen trees are said to also lose all the leaves in oceasional years before the new crop appears. In some species periods of sparse foliation oceur two or three times per year and in others the foliage is more copious on alternate years. It is held that the absence of any very marked periodicity in the environment permits some plants to follow their inherent periodicity of growth, while the annual variation in the transpiration rate and atmospheric moisture are thought to be the cause of the deciduous habit of others.

These observations on foliar periodicity by Dingler, Wright and others seem to show that Dingler may be correct in his contention that leaf-fall is more dependent upon the normal duration of life of the leaves than upon the environment. However, if that should prove to be a fact, it would necessarily follow that certain plants are deciduous not because of the leaf-fall but on account of the failure of a new crop of leaves to develop before the old ones drop. Such a view centers attention upon the causes inhibiting growth rather than upon the causes of leaf-fall in the study of periodicity, a method of attack adopted by Klebs in the paper cited abore. 
It seems then that although trees having annual or more properly radial-growth rings are distributed all over the arborescent world, one or more factors of their envionment must be effective periodically in order that marked zonation occur. The more or less regular recurrence of cold or dry seasons are the factors usually noted in connection with periodically recurrent vegetative seasons, but doubtless any other recurrent environmental factor influencing growth may also affect zonation, e. g., periodic variation in the supply of inorganic foods as was suggested by Klebs. ${ }^{106}$ It should be noted, however, that wood zonations resulting from recurrent dry periods of the tropies even in deciduous trees are not as marked as those occurring in temperate zones where the dormant period is chiefly due to seasonal variations in the temperature and where consequently a greater seasonal change occurs in the bark pressure.

The causes of the formation of radial-growth rings have been studied mainly in the north temperate zone and, therefore, explanations are largely based on the environmental factors that seem to be operative in that region. Seasonal changes in bark pressure, in the supply of metabolized food to the cambium, and in the rate of transpiration have been either separately or in partial combination advanced as explanations for the occurrence of the large-celled spring-wood alternating with small-celled summer-wood.

The bark-pressure hypothesis:-Sachs ${ }^{107}$ seems to have been the first to suggest that the difference between spring and summer wood may be due to a difference in the bark tension or pressure obtaining in spring and summer. The idea was then tested experimentally by de Vries $^{108}$ with the result that Sachs' hypothesis seemed to have been sustained. The experiments by de Vries consisted in making some longitudinal slits in the outer bark of various trees in spring and of applying ligatures to the stems of other's. On the following winter it was found that only about one-half as many cells had been produced under the ligatures as occurred on other parts of the past season's ring; while in the regions where the outer bark had been slit the number of

${ }^{106} 1$. e.

107 Sachs, von, F. G. J. Lehrbuch der Botanik. 1. Aufl. 1868, p. 403.

${ }^{108}$ Vries, de, $H$. Ueber den Einfluss des Rindendruckes auf den anatomischen Bau des Holzes. Vorläufige Mitlheilung. Flora. 33:97-102. 1875 . 
cells had become two to three times that produced in the normal portions of the ring. Similar experiments also showed that the amount of radial and tangential growth of cells differentiating from the cambium is inversely proportional to the pressure exerted on them. It also seemed that pressure acts as a selecting agent in determining the proportion of vessels to wood fibers; i. e. the greater the pressure the fewer the vessels and the more numerous the wood fibers to be produced. De Vries concluded therefore that bark pressure influences the rate of cambial division as well as the relative size cells may attain during differentiation. Since bark-growth follows the enlargement of the wood cylinder it was thought evident that bark pressure is greater toward the end of the radial-growth period than at its beginning. For these reasons de Vries held that a seasonal change in bark pressure is the chief cause of seasonal growth appearing as "annual", rings.

In some later experiments, while studying wound wood, he $\mathrm{e}^{109}$ found on lifting loose strips of bark with a knife on the concave side of young tree-trunks held in a bent position, and then tying it in place again in such a way as to prevent evaporation, that numerous large vessels developed in the new wood produced under the strips. He reiterated his former conclusion that bark pressure is an important factor in determining the size of wood cells and that it is largely responsible for the difference between spring and summer wood.

That bark tension does occur on enlarging stem structures had been shown by Kraus ${ }^{109}$ as well as by Nördlinger ${ }^{110}$ but neither of them secured quantitative results of value.

The influence of pressure on cambial activity and cell differentiation have since been investigated from various viewpoints and have led to different conclusions. Höhnei ${ }^{111}$ found sharpangled transverse displacements in the bast fibers of many Dicots at points where neighboring cells make an abrupt uneven

${ }^{100}$ Vries, de, H. Ueber Wundholz. Flora. 34:2-8; 17-25; 38-45; 49-55; 81-88; 97-108; 113-21; 129-39. 1876.

${ }^{100}$ Kraus, G. Die Gewebespannung des Stammes und ihre Folgen. Bot. Zeit. $25: 105-19 ; 121-33 ; 137-42.1867$.

${ }_{110}$ Nördlinger, H. Spannt die Baumrinde im Sommer nicht? Kritische Blät. Forst-u. Jagdwiss. 52: (1):253-55. 1870.

${ }^{111}$ Höhnel, von, F. Ueber den Einfluss des Rindendruckes auf die Beschaffenheit der Bastfasern der Dicotylen. Jahrb. Wiss. Bot. 
joint. Such transverse displacements or sharp double-bends were found in about two-thirds of the fifty to sixty species examined. They were especially prevalent in Urticaceae, Apocynaceae, Asclepidaceae, Linaceae, etc., while in other families the double-bends occurred only in certain genera. None were found in the Rosaceae including the pomaceous group, nor in the Tiliaceae and Cupuliferae.

It was held that the sharp bends are due to bark pressure, as indicated by the fact that in the plants in which these bends commonly oceur the bast-fibers are but slightly or not at all lignified. Höhnel held that if the double bends were not due to growth or bark pressure they would not always appear at points in the fibers where joints or breaks oceur in the celis of the surrounding tissues. The failure of the bends to become evident until after the tissues are fully differentiated was taken to indieate that bark-pressure becomes greater during the latter part of the differentiation period. It also seemed that in ease of Urtica, Cannabis and Linum the bark pressure was often greater in the lower part of the stem than above, for the anguiar bends were frequently present on the fibers of the lower part while none occurred in the upper. The transverse displacements were found to be made up of two successive sharp bends which were noticeable in all layers of the wall. In many eases some of the layers were actually ruptured.

Krabbe ${ }^{112}$ made extensive studies of bark pressure and tried to obtain some quantitative measurements. He inereased bark pressure by encircling tree-trunks with a chain much like that now used on bicycles, except that it was wider. One end of the chain was fixed to an iron peg driven into the tree and the other ran over a pulley and had a weight pan attached. A piece of tin a little wider than the chain was placed about the trunk under the chain to distribute the pressure more evenly and to reduce friction. Weights were put into the pans in accordance with the determinations of bark pressure obtained before, and it was found that the bark pressure had to be doubled and even quadrupled before any influence on the size of the cells or the thick: ness of the yearly growth became evident.

\footnotetext{
${ }^{112}$ Krabbe, G. Über die Beziehung der Rindenspannung zur Bildung der Jahrringe und zur Ablenkung der Markstrahlen. Sitzungsber. Akad. Wiss. Berlin 1882: 1093-1143. 1882.
} 
The "normal" bark pressure was determined by stretching rings of bark over a smooth cylinder by means of weights until the bark had attained the length it had while still attached to the tree. In his later work ${ }^{113}$ the rings of bark were straightened out and weighted at one end to determine the force required to stretch the bark to its former length, for it was found that the results obtained in this way were the same as those gotten with the more elaborate apparatus. The bark pressure of conifers was found to be usually under one-half an atmosphere and that of broad-leaved trees about twice as great. In case of conifers the pressure seemed to increase in fall on an average about $0.8 \mathrm{gm}$. per square millimeter of cross section, while the average of similar measurements on a number of broad-leaved trees indicated a decrease of pressure in fall equal to $12.5 \mathrm{gm}$. per square millimeter of cross section. He maintained that the breaking strain of bark is never reached by growth pressure. Bark pressure was found greatest in regions of most rapid radial growth, for instance on the side of excentric stems with the longer radius.

By using pressures from five to eight atmospheres the summer-wood type of radial growth was induced in spring on trees having comparatively little difference in the size of spring and summer-wood cells, while on trees having very marked differences between spring and summer wood it was practically impossible to induce the formation of the summer-size of cells in spring by increasing the bark pressure. In reducing the bark pressure by means of longitudinal slits in the outer bark in summer, typical spring wood vessels developed in trees which normally have only a slight difference between size of spring and summer wood cells; but in trees like Quercus and Fraxinus in which a marked difference occurs between spring and summer wood, the spring wood vessels could not be thus induced. Krabbe therefore concluded that bark pressure remains practically the same throughout the growing season and that changes in bark pressure could not be the cause of ring formation because it requires such a great increase to influence the size of the wood cells.

${ }^{113}$ über das Wachsthum des Verdickungsringes und der jungen Holzzellen in seiner Abhängigkeit von Druckwirkungen. Abhandl. Kgl. Akad. Wiss. Berlin. 1884. Anhang. 1:1-80. 1885. 
Gehmacher ${ }^{114}$ also performed some experiments in the increase and decrease of bark pressure on three to six-year-old trees and shrubs. The outer cortex was slit in February and nearby on the same stem a ligature of tightly wound wire was applied and the stem allowed to grow until the end of the season.

The number of cork cells varied inversely as the pressure and their radial diameter was decreased by $11 \%$ under increased bark pressure, while under reduced pressure an increase of $13 \%$ above normal resulted. A similar effect was noted on the cortical parenchyma cells except that both the radial and tangential diameters were decreased under increased pressure and the intercellular spaces were obliterated, while under reduced pressure the cells became globular and the intercellular spaces were increased in size above the normal. The difference between the thickness of the cortical parenchyma under increased and that under decreased pressure was enormous. In the wood the number of fibers increased and that of vessels decreased under added pressure, while the number of bast fibers was greatly reduced by increased pressure. Gemacher's conclusion was that it does not require the enormous differences of bark tension to influence the size of wood cells as had been maintained by Krabbe.

Hoffman ${ }^{115}$ also investigated the influence of pressure on cell division and differentiation in the cambium of trees and concluded that the forces which contribute to the development of cylindrical stems rather than some other form are (1) bark tension and the consequent bark pressure, (2) radial-growth pressure, and (3) the passive resistance of the wood. Cambial division and growth are said to continue only as long as growth pressure exceeds bark pressure and it is thought that if bark pressure is equal on all sides the axis must either be or soon will become cylindrical on occurrence of continued radial growth. This is shown by the fact that angular young shoots become cylindrical on growing older. Even when the tension of the bark is the same all around a branch bark pressure may be different at different points, being considerable at prominences and

\footnotetext{
${ }^{114}$ Gehmacher, A. Untersuchungen über den Einfluss des Rindendruckes auf das Wachstum und den Bau der Rinden. Stizungsber. K. Akad. Wiss. Wien. 88 Abt. 1:878-96. 1884.

${ }^{115}$ Hoffman, R. Untersuchungen über die Wirkung mechanischer Kräfte auf die Teilung, Anordnung und Ausbildung der Zellen beim Aufbau des Stammes der Laub- und Nadelhölzer. Inaug. Dissertation. Berlin. 1885. pp. 24.
} 
perhaps zero or even negative in depressions. Among the numerous angular young twigs examined the greater pressure at the angles did not prevent the development of normal spring wood, but larger numbers of both spring and summer wood cells were produced in the depressions than on the ridges until the twig became cylindrical.

It was found that when a tree-trunk or branch presses against some non-yielding object or the bases of the component branches of a forked stem press against each other, radial growth is reduced on the side of contact when the pressure has reached a certain intensity and that the rays spread outward and eventually became parallel to the obstructing surface. The continuance of radial growth tends to separate or pull apart the components of a forked stem or widen the upper angle a branch makes with its axis. Branches thus firmly pressed against each other eventually fuse and the rays then come to radiate from the common center and further radial growth tends to result in a cylindrical, united structure. It was found that the callus developing at the cut end of a twig in water also conformed to the general law of the mechanies of radial growth in that its cross sections become semicircular with a rough outline; but the surface becomes smooth as tension is developed by further growth. When a rectangular piece of bark was cut from a tree the first division of the cambium in the formation of a callus is said to be by a radial wall or one at right angles to the wall formed under normal conditions. Further growth and division was also found to occur in accordance with the resistance to growth and resulted in a structure having its center at the place where the first cambial divisions took place. The rays in the bark on both sides of the piece cut out become diverted not only by the contraction of the bark at the time the piece was cut but also by the lack of surface growth in the bark surrounding the wound. The omission of surface growth is said to be due to the lack of accustomed tangential pull formerly exercised by the excised piece. Growth is resumed only after the callus bark has reached a tension comparable to that of the piece removed. This resulted in increased radial growth in the entire region influenced by the wounding, as shown by a count of the number of cells produced here as compared to that produced in other places. When the cambium was first freed from its normal bark pres. 
sure its cells took on isodiametric forms which were retained until the bark pressure became appreciable again and then reverted back to the elongate form normal to the species. It is held that the upper and lower edges of a wound do not produce callus as copiously as the lateral ones because of the lesser reduction of bark pressure, and the death of the eut cells which extend some distance above and below the wound.

From his experiments in which ligatures were applied to stems Sorauer ${ }^{116}$ concluded that slow radial growth combined with high bark pressure results in twisted grain and that a reduction of bark pressure below normal not only induces more cells to form from the cambium, but cells having a greater diameter and a reduced length.

Newcombe ${ }^{117}$ found that when external conditions prevent growth, the unfinished tissues remain unaltered and thin walled; that mechanical resistance or pressure prolongs the differentiattion period, the cells remaining smaller and thinner walled.

The occurrence of numerous cocoons of bag-worms on various species of trees and the fact that the narrow silken bands by which they are attached to the twigs are often too strong for radial growth pressure to break, afforded von Schrenk ${ }^{118}$ an occasion for a study of the effects of excessive pressure on radial growth. In most eases the silken bands encireling the twigs are burst early in the summer of the year following the time of the attachment of the bags. In some instances in which the ligatures were too strong to be luptured by the thickening twigs the transfer of elaborated food was eventually checked and an enlargement developed on the distal side of the constricting band. In other cases the ligature was sufficiently distended by growth to permit of some food transfer and resulted in the formation of welts on both sides of bands. In some instances the pairs of welts fused above the ligatures and reestablished normal connection and pressure. In arbor vitae the wood fibers of the first

110 Sorauer, P. Handbuch der Pflanzenkrankheiten. Dritle Auflage. 1:764-66. 1909 .

${ }_{117}$ Newcombe, F. C. The influence of mechanical resistance on the development and life-period of cells. Bot. Gaz. 19:149-57; 191-99; 229-36. 1894.

${ }^{118}$ Schrenk, von, H. Constriction of twigs by the bag-worm and incident evidence of growth pressure. Ann. Rpt. Mo. Bot. Gard. 17:153-81. 1906. 
year's growth were often found arranged at right angles to the axis, under unbroken bands.

In the latter part of the second summer following the attachment of the bags the portion of the twigs distad to the constriction had much starch in the bark rays and pith, while that on the basad side was practically devoid of it.

In hard-wood trees both bark and wood were found to have continued growing under unbroken bands though welts developed on both sides. The first wood cells formed under the ligatures were normal but those developing afterwards had a shorter racial diameter and thicker walls than those under normal pressure. The number of vessels appeared to decreaes in proportion to the pressure. The wood fibers developing under high pressure were found to have their long axis at right angles to the twig or parallel with the compressing band, and the rays were bent or buckled laterally unded pressure. It is held that the increased pressure induces the formation of smaller wood cells not because cambial division occurs before the cells have attained the normal size but because the pressure hinders their enlargement during subsequent differentiation.

A large number of tests made to determine the breaking strain of the bands from both conifers and broad-leaved trees showed it to be about 40 atmospheres; and, therefore, indicates that Krabbe's experimental results showing a growth pressure of 15 atmospheres are too low, since von Schrenk's observations show that the majority of the bag-worm ligatures are ruptured by the enlarging twigs.

An osmotic-pressure hypothesis.-In a paper on the development of pits in the wood cells of the Abietineae Russow ${ }^{119}$ suggested another explanation of "annual" rings. He claimed that the bark pressure hypothesis of Sachs which de Vries endeavored to support by experiment, cannot account for the occurrence of growth rings in the wood because the last phloem cells of a season do not have a reduced radial diameter and on account of the fact that two rings may be induced by defoliating trees. The bark-pressure hypothesis is also held to be discredited by the occurrence of growth rings in the tropies where

119 Russow, E. Úber die Entwicklung des Hoftüpfels, der Membran der Holzzellen und des Jahresringes bei den Abietineen, in erster Linie von Pinus silvestris L., Sitzungsber. Naturfor. Ges. Dorpat 6: 147-57. 1884 . 
the bark is not distended by low temperature during a dormant season. In another paper he $\mathrm{e}^{120}$ added that in accordance with the bark-pressure hypothesis the wood cells in roots ought to be small while as a matter of fact they are large. On the other hand he held that the changes in the radial diameter of cells from spring to fall can easily be explained by assuming the presence in them of highly osmotic substances, which induce a high hydrostatic pressure and as a result give rise to large cells in spring, while toward the end of the radial-growth period the hydrostatic pressure in differentiating cells is reduced owing to a reduction of the osmotic pressure in them. By using solutions of glycerine as plasmolysing agents Wieler ${ }^{121}$ found that osmotic pressure in herbaceous plants was less than that in the living wood and ray cells of trees where it ranged from 13 to 21 atmospheres. No difference was found, however, between the osmotic pressure in differentiating wood ressels and of that in the cambium cells. He thought that the walls of differentiating spring-wood cells are more distensible than those of summer wood owing to their lower cellulose content.

Seasonal variation in the available elaborated food as the cause of "annual" rings:-After years of intimate study of forest trees Hartig ${ }^{122}$ concluded that since radial growth begins in spring under suboptimal environmental conditions and while the new leaves are very small or the buds are just bursting, the nutritive conditions 'of the cambium must also be suboptimal and for that reason the spring wood has thin cell walls. As the season advances the leaves attain full size which in connection with the accompanying seasonal changes are conducive to the man. ufacture of the larger quantities of organic foods which, according to Hartig, are responsible for the production of the thicker walled summer-wood cells. It is held that the chief difference between spring and summer wood consists essentially in the thickness of the cell walls and that the improvement in the nutrition of the cambium from early spring until the later summer is re-

${ }^{120}$ Russow, E. Über den Inhalt der parenchymatischen Elemente der Rinde vor und während des Knospenaustriebes und Beginns der Cambiumthätigkeit in Stamm und Wurzel der einheimischen Lignosen. Sitzungsber. Naturfor. Ges. Dorpat. 6: 388-89. 1884.

${ }_{121}$ Wieler, A. Beiträge zur Kentniss der Jahresringbildung und des Dickenwachstums. Jahrb. Wiss. Bot. 18: 70-132. 1887.

${ }^{12}$ Hartig, R. Ein Ringlungsversuch. Allgem. Forst-u. Jagd-Zeit. 65: 365-73; 401-410. 1889. 
sponsible for the occurrence of "annual rings." Hartig stated however, that the differences in the nutritive conditions caunot account for the change in radial diameter of wood cells nor for the presence of the larger proportion of vessels in spring wood, and maintained that the transpiration current determines their size. He suggested that the reason so little difference exists in the radial diameter of spring and summer wood cells of Populus, Salix, Acer, etc., is to be found in the fact that these trees continue producing new leaves throughout most of the radial growth period and because they have no duramen. Since the water current in trees with duramen is necessarily confined to the outer layers of wood its effects on cells differentiating from the cambium are thought to be more marked and therefore result in greater differences in the diameter of spring and summer wood cells, e. g. in oaks, etc. According to Hartig, then, "annual" rings are primarily due to the poor nutritive conditions of the cambium in spring being followed by a period of more abundant supply of metabolized food in summer, and secondarily to a decrease in the intensity of the transpiration current toward the end of the radial-growth period.

Wieler ${ }^{123}$ came to a diametrically opposed conclusion regarding the differences in the nutritive conditions about the cambium in spring and summer. He thought that since the characteristies of "annual" rings lie in the type of wood produced in the early and late growing season and not in the succession of rings, the relation of different nutritive conditions to the formation of spring and summer xylem could be more easily determined experimentally with herbaceous than with woody plants. This was deemed permissible owing to the fact that in an examination of 54 species of herbs belonging to 21 families the characteristic reduction in the size of the xylem cells toward the end of the growing season as is typical of the "annual" rings of woody plants, was found in over half of them.

Seedlings of Ricinus communis were set into the soil of onefourth to one-half liter pots in spring, well watered and given optimum light and temperature conditions, but they grew slowly and remained dwarfs. In early summer four of them were transplanted to the soil in a field and three of them into good soil in four liter pots. Those remaining in small pots were 
only about $27 \mathrm{~cm}$. high in January and their stems about $21 \mathrm{~mm}$. in circumference, while those in four liter pots were about 90 em. high and $50 \mathrm{~mm}$. in circumference. Those transplanted to the ficld beeame large plants with woody stems. Five dwarfed plants, which were subsequently transplanted to a forcing bed, had since made a rank growth and were retransplanted to four liter pots. They wilted but eventually recovered their turgidity, although the older leaves died.

Cross sections showed the xylem cells of the field plants to be larger and the vessels more numerous than in those retained in the small pots. In the plants transplanted to the field the xylem cells around the pith were small and were surrounded by larger ones toward the periphery. In case of those transplanted to four liter pots the same inversion of the normal position of large and small celled xylem occurred, but in addition the outermost rows again had a much reduced radial diameter. In the field plants which had been retransplanted to pots the outermost cells also had a reduced radial diameter and thick walls while within them was a zone of large, thin-walled cells which had apparently been formed just before the last transplanting and as a result their walls remained unthickened. Similar results were also obtained with Helianthus annuus. Wieler concluded from these experiments that the abundant supply of metabolized food to the cambium is the most important factor in the production of spring wood and that the shortage of such a food supply induces the formation of summer wood, and that therefore "annual" rings of trees are due to an abundant supply of organic food to the cambium in spring and a reduced supply in summer.

$L_{u t z}{ }^{124}$ was of the opinion that when the food supply to a rapidly dividing cambium is comparatively low while water is abundant the cells become large and thin-walled as is characteristic of spring wood, while if the food supply is good and the water is low the cells become small and thick-walled as in summer wood.

In a later paper Wieler ${ }^{125}$ reiterated his former conclusions though he admits his inability to prove that the small radial

${ }^{124} 1$. c.

${ }^{125}$ Wieler, A. Ueber die Abhängigkeit der Jahresringbildung von den Ernährungsverhältnissen. Allgem. Forst-u. Jagd-Zeit. 67: 82-89. 1891 
diameter of summer-wood cells results from a reduced supply of food to the cambial region; nevertheless, it is held to be a more likely contention than that maintained by Hartig to the effect that summer-wood results from an increase in the supply of metabolized food.

In this paper Wieler eited similar experiments by Sachs ${ }^{126}$ in support of his conclusions, although Sachs noted that the frequent addition of abundant nutrient solution failed to induce more growth in small pots. Sachs held the dwarfing in small pots to be due to a crowding of the root system into mats in such a way as to greatly impair their absorptive functions.

The relation of rest and food supply to the production of wood rings:-Mer ${ }^{127}$ held that the winter rest of the cambium and its consequent great activity in spring in connection with the abundance of plastic materials at that time are the causes of the production of large-celled spring wood. The cell walls of spring wood are thought to remain relatively thin because the food transfer through such a thick differentiating zone of cells is 'comparatively slow, and the thick walls of summer wood cells are assumed to be due to slow rate of cambial division or to the thinness of the differentiating zone and consequent ready access of organic food to its cells. The sudden and considerable decrease in the radial diameter of the peripheral few rows of wood cells in a year's growth is held to be due to an arrest of their development as a result of enfeebled cambial activity rather than to an increase of bark pressure as maintained by Sachs, de Vries and others.

A summary and comparison of the hypotheses:-The work of Kraus, de Vries, Nördlinger, Detlefsen, von Höhnel, Gemacher, Hoffman, Kny, Newcombe, von Schrenk, and Sorauer, have made it apparent that pressure on the cambium affects the rate of cell division as well as the size differentiating wood cells may attain, but owing to the fact that no method has as yet been developed by means of which quantitative measurements of bark pressure can be made it is impossible to determine just what relation bark pressure has to the production of "annual", rings.

${ }^{126}$ Sachs, von, F. G. J. Vorlesungen über Pflanzenphysiologie.* Leipzig. 1882. p. 623 .

${ }^{127} 1$. C. 
The different degrees of hydrostatic pressure assumed by Russow as the cause of the difference between spring and summer wood has apparenty also been implied by Hartig, Mer and others in speaking of growth force, etc., but even more than in the former case do the few qualitative tests need to be replaced by quantitative measurements before the validity of the idea could be tested.

Hartig has collected a mass of observational and even some indirect quantitative data that seem to support his hypothesis that the relative abundance of elaborated food determines the thickness of cell walls and that the relative intensity of the transpiration stream determines the length of the radial diameter of wood cells, but the experiments of Jost, Lutz and others show that although food and water may be present in great abundance very little or no radial growth occurs when terminal growth is prevented.

Wieler's hypothesis that the abundance of metabolized food in the cambial region in spring induces the formation of spring wood and its reduction, summer wood is also lacking in that it does not account for the cessation of radial growth on the removal of the elongation structures. Besides, the experiments with which he assumes to have made his contention probably involved too many unknown variables to afford even a satisfactory test of the hypothesis.

The results obtained by Morgulis ${ }^{128}$ in his experiments in alternately feeding and starving salamanders tend also to make one skeptical regarding the value of the hypotheses of both Hartig and Wieler as explanations of ring formation because Morgulis found "That the rate of growth is independent of the amount of nutrition" and that "The impulse to grow plays the leading part" and "determines the degree of utilization of the nutriment." Finally, he found too that "From all that has preceded, the conclusion can be drawn that periodic starvation is more detrimental to the organism than acute starvation followed by a liberal supply of food. In the former case the individual remains below the level of the normally fed animals; in the latter case, on the contrary, provided the inanition has

\footnotetext{
${ }^{128}$ Morgulis, S. The influence of protracted and intermittent fasting upon growth. Amer. Nat. 47: 477-87. 1913.
} 
not been carried too far, the restorative process may go even beyond the limit attainable under normal conditions."

Since Hartig laid especial stress on the difference in the thickness of cell walls rather than the size of cells as the essential difference between spring and summer wood his secondary factor, the relative intensity of the transpiration current, would come in for first consideration because it is claimed to regulate the size of cells. It seems possible that the full report promised by Jaccard ${ }^{129}$ on the tree-trunk as a shaft of equal water conductance may throw more light on Hartig's idea.

The possible relation of enzymes to the formation of "annual" rings:-In cases of this kind in which the hypotheses are so numerous and the advocates of each can marshal at least a portion of the observed facts in support of their views the truth usually lies somewhere hetween them, and each conflicting explanation will eventually contribute certain fragments to a theory that will account for the known facts. The time for such a theory has not yet come. However, since none of the proposed hypotheses gives promise of becoming such an explanatory theory it may be pardonable to submit yet another with the hope that the viewpoint thus suggested might lead to a new attack on the problem.

From our present knowledge it seems that to be of any value as a basis for work or a stimulus for the further study of radial growth rings such an hypothesis must, by using all known and some probable but undetermined facts explain how it is that wood cells have a smaller radial diameter in summer than in spring and why vessels are often wholly lacking in the later summer wood.

It has been shown that an "annual" ring consists essentially of a sheath or ring of wood produced during one more or less continuous radial-growth period and that it is made up of two types of wood which may merge gradually into each other or join at a rather abrupt line. That portion of the ring developed in "spring" or during the early part of a new elongationgrowth period has larger cells than that produced in "summer" or after the closing of the first elongation, following the principal dormant season. In the case of trees in temperate zones and many of those in the tropics which produce new leaves near-

120 1. C.

5-S. A. 
ly throughout the vegetative season the growth rings are not very marked though they are usually apparent. Generally the most reliable criterion for distinguishing the rings is the reduction in the radial diameter of at least the last row or two of rood cells; yet in the tropies histologica! distinctions are said to be practically absent in some trees, and their rings may only be distinguished by slight demarking lines.

The work reviewed in this paper has shown that the environmental factors which control elongation growth also infuence racial growth and that ordinarily the prevention of elongation by tire removal of vegetative points hinders growth in thickness even when the environmental conditions are optimal and the food aud water supply abundant. Klebs ${ }^{130}$ assumed, in fact, that large quantities of organic foods accumulating in plants inactivates the enzymes concerned in elongation and therefore brings about a cessation of growth in length. According to him a timely increase in the water and inorganic nutrients may reactivate or prevent inactivation of the growth enzymes and thereby shorten or eliminate the dormant period.

With such a precedent one may also assume the presence of enzymes which incite and maintain radial growth since there are a number of phenomena to be noticed in connection with growth in thickness that support such an assumption, as may be cathered from the following papers.

In an investigation on the reserve food in seeds Reiss ${ }^{131}$ found that cellulose is laid down on the inner side of cell walls of many seeds and that it is largely redissolved on germination. Schulze ${ }^{122}$ made a similar stuciy of lupine seeds and found convineing evidence that the inner layers of the cotyledonary cell walls are used up during germination. It seemed that the dissolving part of the walls is a hemicellulose which gives rise to galactese and arabinose on hydrolysis. Grïss ${ }^{133}$ a'so noted the nceurence of the hemicelluloses, galactan and araban, in plant

\footnotetext{
${ }^{133}$ Grüss, J. Ueber Lösung und Bildung der aus Hemicellulose bestehenden Zellwände und ihre Beiziehung zur Gummosis. Bibilo. Bot. 39. 1836. pp. 14.

1301. c.

${ }^{133}$ Reiss, R. Ueber die Natur der Reservecellulose und über ihre Auflösungsweise bei der Keimung der Samen. Ber. Deut. Bot. Ges. 7: 32229. 1889 .

${ }^{132}$ Schulze, E. Ueber die Zellwandbestandtheile der Cotyledonen von Lupinus lutens und Lupinus angustifolius und über ihr Verhalten während des Keimungsvorgangs. Ber. Deut. Bot. Ges. 14: 66-71. 1896.
} 
cells, and that they may be dissolved or converted into gum by enzymes. Potter ${ }^{134}$ called attention to the presence of an inner celiulose layer in the xylem cclls of many normal trees, and to its especial abundance in the wood fibers of Quercus, Fagus, Aesculus, Salix, Ulmus, Alnus, and Betula. He fomd that after keeping wood in water during some days cellulose linings became apparent in many cells in which none had been noted before the water treatment.

Du Sablon ${ }^{135}$ concluded that when starch disappears in late fall much of it is converted into reserve cellulose which is deposited on the inner side of wood-cell walls. In some cases this lining was found to be comparativey thick and cecasionally it eren had folds extending into the lumen of cells. It is said to be readily soluble in dilute hydrochloric acid.

Schcllenberg ${ }^{136}$ made a more thorough study of the deposition and partial solution of hemicellulose in the wood and bark of trees. He found a hemicellulose lining on the walls of fibers in loth spring and summer vood of Acsculus Hippocastanum, Tetula and other trees but it was not dissolved in spring. Since sinilar hemicellulose linings in the eells of the phloem and cortical parenchyma were found corroded in spring he concluded that the lining did not dissolve in the fibers because protoplasm was absent there. In the wood fibers of Vitis and Robina Pserdacacia he noted the occurrence of especially thick hemicelulose layers in well matured wood and of much thinner ones in those of immature wood. The protoplasm remains alive in the wood fibers of Vitis and he accordingly found the inner laycrs corroded and dissolved in spring. Ife also found the same solution of the inner unlignified layers in the bast fiber's and cortica lparenchyma and collenchyma of Fraxinus excelsior. Usually from a third to half of the unlignified layer in the eortieal parenchyma is dissolved when the buds open. He was of the opinion that the deposition of hemicellulose in the bark parenchyma continues after the leaves fall.

From these papers it is evident that a hemicellulose dissolving enzyme is active during the early part of a vegetative sea-

\footnotetext{
${ }^{134}$ Potter, M. C. On the occurrence of cellulose in the xylem of woody stems. Ann. Bot. 18: 121-40. 1904.

${ }^{185} \mathrm{l}$. c.

${ }^{186}$ Schellenberg, H. C. Ueber Hemicellulosen als Reservestoffe bei unsern Waldbäumen. Ber. Deut. Bot. Ges. 23: 36-45. 1905.
} 
son and that such an enzyme is not present or is inactive in the latter part of the growing period as indicated by the fact that hemicellulose is deposited in both the wood and bark at that time. Sanio ${ }^{137}$ found that in Pinus silvestris lignification did not occur in spring wood until after the deposition of the seconlary thickening had been completed, that it began at the angles of the cells and then involved the radial walls and later the tangential walls. In the summer wood, however, the primary walls were found to have lignified before the deposition of the secondary thickening began, and it occurred in cells which were only a few removed from the cambium. The final composition of the cell walls of spring and summer wood seem also to differ, for according to Wieler, ${ }^{138}$ the walls of spring wood contain a lower percentage of cellulose than those of summer wood.

If the deposition and lignification of cellulose are in any way dependent upon enzymotic action, there must be at least two enzymes concerned because the two processes appear to be independent of each other as indicated by Sanio's observations. It is evident that either of the processes would necessarily impede or check further enlargement of cells differentiating from the cambium. It, therefore, appears permissible to assume that the enzymes involved in the solution of hemicellulose and the tardiness of the lignification process in spring are important factors in permitting the development of larger wood cells in spring than those produced in summer, when the cellulose dissolving enzymes are inactive and lignification oceurs so quickly after a cell is formed that in some cases it takes place even before secondary thickening has begun. The experiments by Jost and by Lutz also give support to the idea that radial growth is largely controlled by enzymotic activities which are somehow dependent upon the process of terminal elongation. Perhaps the enzymes concerned are liberated or activated in enlarging and bursting buds in different parts of trees and are carried downward in the metabolized food, or possibly enzymes produced in the enlarging buds simply initiate certain activities which are transmitted without the further aid of the enzymes as was assumed by

${ }^{137}$ Sanio, K. Anatomie der gemeinen Kiefer (Pinus silvestris L.). Jahrb. Wiss. Bot. 9: 66-68. 1873.

${ }^{133}$ l. C. 
Fick ${ }^{139}$ regarding the action of the enzymes which coagulate blood and milk.

The fact that stems and branches of trees are more pliable and easily bent while in the midst of active spring growth than they are at any other time, indicates that perhaps some enzymotic softening of the mature wood occurs during the period of most active growth. The upward bending of a branch on a decapitated conifer also argues for the presence of some softening agent during the time of most vigorous growth because of the fact that such branches often bend in response to gravity at places where lignification had previously occurred. In other words, it seems that one of the most important factors in the production of large wood cells in spring and smaller ones in summer may be the presence of enzymes which retard lignification and prevent rapid thickening of the walls and thereby permit growth or hydrostatic pressure to develop large cells in spring; while the abseince or inactive condition of those enzymes induces rapid thickening and early lignification of the walls in summer and thus checks the enlargement of summer-wood cells.

It may be that the idea of growth force expressed by Detlefsen, Mer and others as well as "the impulse to grow" emphasized by Morgulis imply the same sort of notion as that advanced in the above scheme regarding the possible relation of enzymes to ring formation, but in any case the hypothesis is only a guess based on rather suggestive indirect evidence. Mer's conclusion that the winter rest of the cambium induces its greater activity in spring seems to have something in common with the outeome of some feéding experiments by Morgulis, to the effect that in subjecting salamanders to alternate periods of fasting and liberal feeding a greater growth resulted than by more frequent and abundant feedings. A theory to account for wood rings must also make use of the evidence brought out regarding the effect of variations in bark tension both Iongitudinal and transverse, as well as of the influence of the transpiration stream as suggested by Hartig and more recently elaborated by Jaceard in his discussion of the distribution of radial growth. It should be remembered, however, that transpiration is perhaps greater during the time summer-wood is formed than it is while spring wood develops; to say that larger cells are produced in spring to meet the higher water requirements of the approaching summer explains nothing. 


\section{BIBLIOGRAPHY.}

Bailey, I. W. The relation of the leaf-trace to the formation of compound rays in the lower Dicotyledons. Ann. Bot. $25: 225-41 . \quad 1911$.

- Reversionary character of traumatic oak woods. Bot. Gaz. $50: 374-80.1910$.

- The evolutionary history of the foliar ray in the wood of the Dicotyledons, and its phylogenetic significance. Ann. Bot. 26:647-61. 1912.

Bernbeck, O. Der Wind als pflanzen-pathologiseher Faktor. Inaugural Dissert. Bonn. 1907. pp. 116.

Berthold, G. D. W. Untersuchungen zur Physiologie der pflanzlichen Organization. 2:131-257. 1904.

Cavara, F. Some investigations on the action of wind on plant growth. Expt. Sta. Record. 25: 224-25. 1912.

Choux, P. De l' influence de l' humidité de la sècheresse sur la structure anatomique de deux plantes tropicales. Rev. Gen. Bot. 25: 153-72. 1913.

Christison, D. On the difficulty of ascertaining the age of certain species of trees in Uruguay, from the number of rings. Trans. Bot. Soe. Edinburgh. 18:447-55. 1891.

Cieslar, A. Das Rothholz der Fichte. Centbl. Gesam. Forstwesen. 22 : 149-65. 1896.

- Crancfield, F. Duration of the growth period in fruit trees. Wisc. Agrl. Expt. Sta. Ann. Rpt. 17: 300-8. 1900.

Detlefsen, E. Versuch einer mechanischen Erklärung des excentrisehen Dickenwachsthums verholzter Aschen und Wurzeln. Arbeit. Bot. Inst. Würzburg. 2:670-88. 1882.

Dingler, H. Versuche über die Periodizität einiger Holzgewächse in den Tropen. Sitzungsber. Math.-Physical. Kl. Kgl. Bayer. Akad. Wiss. München. 1911:127-43. 1911.

— U Über Periodizität sommergrüner Bäume Mitteleuropas im Gebirgesklima Ceylons. Sitzungsber. Math.-Physieal. Kl. Kgl. Paỵer. Akad. Wiss. Mïnchen. 1911:21747. 1911. 
Eames, A. J. On the origin of the broad ray in Quercus. Bot. Gaz. 49 : 161-66. 1910.

On the origin of the herbaceous type in the Angiosperms. Ann. Bot. 25:215-24. 1911.

Esbjerg, N. Experiments with windbreaks. Expt. Sta. Record. $23: 435.1910$.

Fabricius, L. Untersuchungen über den Stärke-und Fettgehalt der Fichte auf der oberbayerischen Hochebene. Naturw. Zeit. Land-u. Forstw. 3:137-76. 1905.

Fick, A. Ueber die Wirkungsart der Gerinnungsfermente. Archiv Gesam. Physiol. Mens. Thiere. 45: 293-96. 1889.

Fischer, A. Beiträge zur Physiologie der Holzgewächse. Jahrb. Wiss. Bot. 22 : 73-160. 1891.

Gabnay, F. Die Excentrizität der Bäume. Just's Bot. Jahresber. $20: 100.1894$.

Gehmacher, A. Untersuchungen über den Einfluss des Rindendruckes auf das Washstum und den Bau der Rinden. Sitzungsber. K. Akad. Wiss. Wien. 88, Abt. 1:878-96. 1884.

Gilchrist, M. Effect of swaying by the wind on the formation of mechanical tissue. Report Mich. Acad. Sc. 10:45. 1908.

Goff, E. S. The resumption of root growth in spring. Wise. Agrl. Expt. Sta. Ann. Rpt. 15:220-28. 1898.

Groom, P. The evolution of the annual ring and medullary ray in Quercus. Ann. Bot. 25:983-1003. 1911.

Grossenbacher, J. G. Crown-rot, Arsenical poisoning and winter injury. N. Y. State Agrl. Expt. Sta. Tech. Bul. $12: 367-411.1909$.

Crown-rot of fruit trees : field studies. N. Y. State Agrl. Expt. Sta. Tech. Bul. 23:1-59. 1912.

Grüss, J. Über Lösung und Bildung der aus Hemicellulose bestehenden Zeliwände und ihre Beiziehung zur Gummosis. Biblio. Bot. 39. 1896. pp. 14.

Hall, C. E. Notes on the measurements, made monthly at San Jorge, Uruguay, from January 12, 1885, to January 12, 1890. Trans. Bot. Soc. Edinburgh. 18:456-68. 1891. Hämmerle, J. Zur Organization von Acer Psuedoplatanus. Biblio. Bot. 50:1-101. 1900. 
Hartig, R. Das Rothholz der Fichte. Forst. Naturw. Zeit. 5:96-109; 157-69. 1896.

Holzuntersuchungen. Altes und Neues. Berlin. 1901. pp. 99.

Das Aussetzen der Jahresringe bei unterdrückten Stämmen. Zeit. Forst-u. Jagdwesen. 1:471-76. 1869.

Zur Lehre vom Dickenwachsthum der Waldbäume. Bot. Zeit. $28: 505-13 ; 521-29.1870$.

Ueber den Entwicklungsgang der Fichte im zeschlossenen Bestande nach Höhe, Form und Inhalt. Forst. Naturwiss. Zeit. 1: 169-85. 1892.

— Ein Ringlungsversuch. Allgem. Forst-u. Jagd-Zeit. $65: 365-73 ; 401-410.1889$.

Hartig, Th. Beiträge zur physiologischen Forst-Potanik. Allgem. Forst-u. Jagd-Zeit. $1857: 281-96.1857$.

_ Leber die Zeit des Zuwachses der Bäume. Bot. Zeit. $21: 288-89.1863$.

Hastings, G. T. When increase in thickness begins in our trees. Plant World 3:113-16. 1900. (Se. 12:585-86. 1900.)

Hoffman, R. Untersuchungen über die Wirkung mechanischer Kräfte auf die Teilung, Anordnung und Ausbildung der Zellen beim Aufbau des Stammes der Laub- und Nadelhölzer. Inaug. Dissertation. Berlin. 1885. pp. 24.

Höhnel, von, F. Ueber den Einfluss des Rindendruckes auf die Bęschaffenheit der Bastfasern der Dicotylen. Jahrb. Wiss. Bot. 15: 311-26. 1884.

Holden, R. Reduction and reversion in the North American Salicales. Ann. Bot. $26: 165-73.1912$.

Holtermann, C. Der Einfluss des Klimas auf den Bau der Pflanzengewäche. Anatomisch Physiologische Untersuchungen in den Tropen. Pp. 249. 1907. Leipzig.

Jaceard, P. Eine neue Auffassung über die Ursachen des Dickenwachstums. Naturw. Zeit. Forst-u. Landwirts. $11: 241-79.1913$.

Jahn, E. Holz und Mark an den Grenzen der Jahrestriebe. Bot. Centbl. $59: 257-67$; 321-29; 356-62. 1894.

Jeffrey, E. C. Traumatic ray-tracheids in Cunninghamia sinensis. Ann. Bot. 22: 593-602. 1908. 
Jost, L. Ueber Dickenwachstum und Jahresringbildung. Bot. Zeit. $49: 485-95$; 501-10; 525-31; 541-47; 557-63; $573-79 ; 589-96 ; 605-11 ; 625-30.1891$.

- Ueber Beziehungen zwischen der Blattentwicklung und der Gefässbildung in der Pflanze. Bot. Zeit. 51:89138. 1893.

- Ueber einige Eigenthümlichkeiten des Cambiums der Bäume. Bot. Zeit. $59: 1-24.1901$.

Klebs, G. Willkürliche Entwicklungsänderungen bei Pflanzen. Jena. pp. 166.1903.

Über die Rhythmik in der Entwicklung der Pflanzen. Sitzungsber. Heidelber. Akad. Wiss. Math. Naturw. Klass. 23. 1911. pp. 84.

Knudson, L. Observations on the inception, season and duration of cambium development in the American larch. Bul. Torr. Bot. Club. $40: 271-93.1913$.

Kny, L. Ueber das Dickenwachsthum des Holzkoerpers in seiner Abhaengigkeit von aeussern Einfleusen. pp. 136. Berlin. 1882.

- Ueber den Einfluss von Zug und Druck auf die Richtung der Scheidewände in sich theilenden Pflanzenzellen. Jahrb. Wiss. Bot. 37: 55-98. 1902.

—_ Über das Dickenwachstum des Holzkörpers der Wurzeln in seiner Beziehung zur Lothlinie. Ber. Deut. Bot. Ges. $26: 19-50.1908$.

Krabbe, G. Einige Ammerkungen zu den neusten Erklärungsversuchen der Jahringbildung. Ber. Deut. Bot. Ges. $5: 222-32.1887$.

Über die Beziehung der Rindenspannung zur Bildung der Jahrringe und zur Ablenkung der Markstrahlen. Sitzungsber. Akad. Wiss. Berlin 1882:1093-1143. 1882.

- Über das Wachsthum des Verdickungsringes und der jungen Holzzellen in seiner Abhängkeit von Druckwirkungen. Abhandl. Kgl. Akad. Wiss. Berlin. 1884. Anhang. 1:1-80. 1885.

Kraus, G. Die Gewebespannung des Stammes und ihre Folgen. Bot. Zeit. 25 : 105-19; 121-33; 137-42. 1867.

Kroll, G. H. Wind und Pflanzenwelt. Beihefte Bot. Centralbl. 30 Abt. 1:122-40. 1913. 
74 Wisconsin Academy of Sciences, Arts, and Letters.

Kïlns, R. Die Verdoppeiung des Jahresringes durch künstliche Entlaubung. Biblio. Bot. 70:1-53. 1910.

Lakon, G. Die Bceinflussung der Winterruhe der Holzgewächse durch die Nährsalze. Ein neues Frühtreibenverfahren. Zeit. Bot. 4:561-82. 1912.

Lazniewski, von, WV. Beiträge zur Biologie der Alpenpflanzen. Flora, 82 : 224-67. 1896.

Lutz, K. G. Bciträge zur Physiologie der Holzgewächse. Beiträge Wiss. Pot. 1:1-8. 1897.

Mer, E. Recherches sur les causes d'excentricitè de la moćlle dans le sapins.

_ Sur les causes de variation de la densitè des bois. Bul. Soc. Bot. France. 39:95-105. 1892.

Rev. Eaux et Forêts. Ser. $2: 2: 461-71 ; 523-30 ; 562-72$. $1888 ; 3: 19-27 ; 67-71 ; 119-30 ; 151-63 ; 197-217.1889$.

Netzger, A. Der Wind als massgebender Faktor für das Wachsthum der Bäume. Mündener Forst. Hefte. 3: 35-86. 1893.

- Studien über den Aufbau der Waldbäume und Bestände nach statischen Gesetzen. Mündener Forstl. Hefte. 5: 61-71. 1894. Mändener Forstl. Ilefte. 6:94-119. 1894.

Mohl, von. II. Einige anatomische und physiologische Bemerkungen über das $\mathrm{Holz}$ der Baumwurzeln. Bot. Zeit. 20 : 225-30; $233-39 ; 268-78$; 281-87 ; 289-95; 313-19; 321-27. 1862.

Morgulis, S. The influence of protracted and intermittent fasting upon growth. Amer. Nat. 47:477-87. 1913.

Mïllcr, N. J. C. Beiträge zur Eutwicklungsesehichte der Baumkrone. Bot. Untersuchungen 1:512-24. 1877. Heidelberg.

Neweombe, F. C. The influence of mechanical resistance on the development and life-period of cells. Bot. Gaz. 19 : 149-57; 191-99; 229-36. 1894.

Niklewski, B. Untersuchungen über die Umwandlung einiger stickstoffreier Reservestoffe während der Winterperiode der Bäume. Beihefte Bot. Centralbl. 19 Abt. 1:68-117. 1906.

Nördlinger, H. Der Holzring als Grundlage des Baumkörpers. Stuttgart. 1871. pp. 47 . 
_- Wirkung des Rindendruekes auf die Form der Holzringe.

Centralbl. Gesam. Forstwesen. 6:407-13. 1880.

Die September-Fröste 1877 und der Astwurzelschaden

(Astwurzelkrebs) an Bäumen. Centbl. Gesam. Forstw. 4:489-90. 1878.

__ Spannt die Baumrinde im Sommer nicht? Kritische Blät. Forst-u. Jagdwiss. 52 : (1) : 253-55. 1870. Pfeffer-Ewart. The Physiology of Plants. 2nd revised Ed. 2: 207. 1903.

Preston, J. F. and Phillips, F. J. Seasonal variation in the food reserve of trees. Forest Quarterly $9: 232-43$. 1911.

Potter, M. C. On the occurrence of cellulose in the xylem of woody stems. Ann. Bot. 18:121-40. 190t.

Reiche, K. Zur Kentniss der Lebensthätigkeit einiger chilenischen Holzgewächse. Jahrb. Wiss. Bot. $30:$ 1-11j. 1897.

Reiss, R. Ueber die Natur der Reservecellulose und über ihre Auflösungsweise bei der Keimung der Samen. Ber. Deut. Bot. Ges. $7: 322-29.1889$.

Resa, F. Ueber die Periode der Wurzelbildung. Inang. Dissert. Bonn. 1877. pp. 37.

Rosenthal, M. Über die Aushildung der Jahresringe an der Grenze des Baumwuchses in den Alpen. Inaug. Dissertation. Berlin. pp. 24. 1904.

Rubner: K. Das Hungern des Cambiums und has Aussetzen der Jahrringe. Naturw. Zeit. Forst-u. Landw. 8:212-62. 1910.

Russow, E. Über den Inhalt der parenchymentischen Elemonte der Rinde vor und während des Knospenaustriebes und Beginns der Cambiumthätigkeit in Stamm und Wurzel der einheimischen Lignosen. Sitzungsber. Naturfoischer-Ges. $6: 386-88.1884$.

- Über die Entwicklung des Hoftüpfels, der Membran der Holzzellen und des Jahresringes bei den Abretineen, in erster Linie von Pinus silvestris L. Sitzungsber. Naturfor.-Ges. Dorpat 6: 147-57. 1884.

Sablon, du, Leclere. Recherches physiologiques sur les matières de réserves des arbres. Rev. Gen. Bot. 16:339-68; 386-401. 1904. 
Sachs, von, F. G. J. Lehrbuch der Botanik. 1. Aufl: 1868, p. 409.

— Vorlesungen über Pflanzenphysiologie. Leipzig. 1882. p. 623.

Sanio, K. Vergleichende Untersuchungen über die Zusammensetzung des Holzkörpers. Bot. Zeit. 21:391-99. 1863. - Antomie der gemeinen Kiefer (Pinus silvestris L.). Jahrb. Wiss. Bot. $9: 66-68.1873$.

Schellenberg, H. C. Über Hemicellulosen als Reservestoffe bei unsern Waldbäumen. Ber. Deut. Bot. Ges. 23:36-45. 1905.

Schrenk, von, H. Constriction of twigs by the bag worm and incident evidence of growth pressure. Ann. Rpt. MIo. Bot. Gard. $17:$ 153-181. 1906.

Schwarz, F. Physiologische Untersuchungen über Dickenwachstum und Holzqualität von Pinus silvestris. Berlin. 1899. pp. 371.

Schweinfurth. Sitzungsber. Ges. Naturfor. Freunde. Berlin. 1867. p. 4.

Schwendener, S. Das mechanische Princip im anatornischen Bau der Monocotylen mit vergleichenden Ausblicken auf die übrigen Pflanzenklassen. pp. 179. 1874.

_ Zur Lehre von der Festigkeit der Gewächse. Sitzungsber. K. Preuss. Akad. Wiss. Berlin. 1884: 1045-70. 1884.

Schulze, E. Ueber die Zellwandbestandtheile der Cotyledonen von Lupinus lutens und Lupinus angustifolius und über ihr Verhalten während des Keimungsvorgangs. Ber. Deut. Bot. Ges. 14:66-71. 1896.

Smith, A. .M On the application of the theory of the limiting factors to measurements and observations of growth in Ceylon. Ann. Roy. Bot. Gard. Peradeniya. 3:303-75. 1906.

Soraner, P. Handbuch der Pflanzenkrankheiten. Zweite Auflage. 1:537. 1886 .

- Handbuch der Pflanzenkrankheiten. Dritte Auflage. 1:764-66. 1909.

Späth, H. L. Der Johannistrieb. Ein Beitrag zur Kenntniss der Periodizität und Jahresringbildung sommergrüner Holzgewächse. Berlin, 1912. pp. 91. 
Strasburger, E. Ueber den Bau und die Verrichtungen der Leitungsbahnen in den Pflanzen. Histologische Beiträge $3: 494$. 1891 .

Thompson, W. P. On the origin of the multiseriate ray of the Dicotyledons. Ann. Bot. 25:1005-14. 1911.

Tower, W. V. Insects injurious to citrus fruits and methods for combating them. Porto Rico Agrl. Expt. Sta. Bul. $10: 16-20 ; 35.1911$.

Tubeuf, von, K. Beobachtungen über elektrische Erscheinungen in Walde. Naturiw. Zeit. Land-u. Forstw. 3:493-507. 1905 .

Urspruing, A. Zur Periodizität des Dickenwachstums in den Tropen. Bot. Zeit. 62: Abt. 1:189-210. 1904.

__ Beitrag zur Erklärung des excentrischen Dickenwachstum. Ber. Deut. Bot. Ges. $19: 313-26.1901$.

Vöchting, II. Zur experimentellen Anatomie. Nachrichten. Kgl. Ges. Wiss. Göttingen. 1902: 278-83. 1902.

Vries, de, H. Ueber den Einfluss des Rindendruckes auf den anatomischen Bau des Holzes. Vorläufige Mittheilung. Flora. $33: 97-102 . \quad 1875$.

Ueber Wundholz. Flora. 34:2-8; 17-25; 38-45; 49-55; $81-88 ; 97-108 ; 113-21 ; 129-39.1876$.

Waldron, C. B. Windbreaks and hedges. N. Dk. Agrl. Expt. Sta. Bul. 88. 1910. pp. 11.

Wieler, A. Ueber den Antheil des secundären Holzes der dicotyledonen Gewächse an der Saftleitung und über die Bedeutung der Anastomosen für die Wasser-versorgung der transpirenden Flächen. Jahrb. Wiss. Bot. $19: 82-137.1888$.

- Beiträge zur Kentniss der Jahresringbildung und des Dickenwachistums. Jahrb. Wiss. Bot. 18:70-132. 1887. Ueber die Abhängigkeit der Jahresringbildung von den Ernährungsverhältnissen. Allgem. Forst-u. JagdZeit. $\quad 67: 82-89 . \quad 1891$.

Wiesner, J. Ueber das ungleichseitige Dickenwachsthum des Holzkörpers in Folge der Lage. Der Deut. Bot. Ges. $10: 605-10 . \quad 1892$.

Wotczal, E. Die Stärkeablagerung in den Holzgewächsen. Bot. Centralbl. 41:99-100. 1890.

Wright, H. Foliar periodicity of endemic and indigenous trees in Ceylon. Ann. Roy. Bot. Gard. Peradeniya $2: 415-$ 





